\title{
İslami ve Konvansiyonel Hisse Senedi Endekslerinin Oynaklıkları Üzerine Bir İnceleme ${ }^{1}$
}

\author{
Fatih GÜCLLÜ²
}

$\ddot{O} z$

Bu çalışmanın amacı, Türkiye, Malezya, A.B.D. ve İngiltere İslami ve konvansiyonel hisse senedi endekslerinin oynaklıklarının tahmin edilmesi ve tahmin edilen oynaklikların hem ülke hem de İslami hisse senedi endeksleri bazında karşılaştırılmasıdır. Oynaklıklar, ARCH tipi modellerden GARCH, EGARCH ve GJR-GARCH modeller kullanılarak tahmin edilmiştir. Karşılaşıtırma ise kaldıraç etkisinin varllğı, oynaklıktaki kalıcılık etkisi, oynaklık yarılanma süresi, uzun dönem ve kısa dönem oynaklık ölçütlerine göre yapıllmıştır. Çalışmanın sonuçlarına göre, kaldıraç etkisinin varlığının tespit edilmesine olanak tanıyan EGARCH ve GJR-GARCH modellerin en iyi tahmin modeli olarak belirlendiği piyasaların tümü için kaldıraç etkisinin varlığı saptanmıştır. Türkiye İslami hisse senedi endeksinin oynaklığı konvansiyonel emsalinden daha düşük iken, Malezya'da oynakliklar birbirine çok yakın, A.B.D. ve İngiltere'de ise İslami hisse senedi endeksinin oynaklığı konvansiyonel endeksten daha yüksek tahmin edilmiştir. İslami hisse senedi endeksleri arasında ise en düşük oynaklığa sahip endeks Malezya’ya aittir. Malezya’nın ardından sırasıyla İngiltere ve A.B.D. gelirken, Türkiye İslami hisse senedi endeksi oynaklığın en yüksek olduğu endekstir.

Anabtar Kelimeler: İslami Finans, İslami Hisse Senedi Piyasaları, Oynaklık

\section{A Study on the Volatility of Islamic and Conventional Stock Indices}

\section{Abstract}

The aim of this study is to forecast the volatility of Islamic and conventional stock indices of Turkey, Malaysia, USA, and UK and to compare the forecasted volatilities. The volatilities were forecasted using GARCH, EGARCH and GJR-GARCH models which are ARCH-types models. The comparison was made according to volatility persistence, half-life volatility, long-term volatility, short-term volatility and the existence of leverage effect. According to the results of the study, the existence of leverage effect is determined for all the markets where EGARCH and GJRGARCH models are the appropriate estimation models. Turkey Islamic stock index volatility is lower than the conventional counterpart while the volatilities of Malaysian indices are nearly same. However, the volatility of the Islamic stock indices of USA and the UK are higher than their conventional counterparts. Malaysian Islamic stock index has the lowest volatility among Islamic stock indices while Islamic stock index of Turkey has the highest volatility.

Key Words: Islamic Finance, Islamic Stock Markets, Volatility

Atıf İçin / Please Cite As:

Güçlü, F. (2020). İslami ve konvansiyonel hisse senedi endekslerinin oynaklıkları üzerine bir inceleme. Manas Sosyal Arassturmalar Dergisi, 9(2), 1070-1088.

Geliş Tarihi / Received Date: 22.05.2019

Kabul Tarihi / Accepted Date: 17.09.2019

\footnotetext{
${ }^{1}$ Bu çalışma, Dr. Öğr. Üyesi Metin KILIÇ’ın danışmanlığında tamamlanan, Fatih GÜÇLÜ’ye ait “İslami Hisse Senedi Piyasaları ile Geleneksel Hisse Senedi Piyasaları Üzerine Karşılaştırmalı Bir Analiz: A.B.D., İngiltere, Malezya ve Türkiye Örneği” isimli doktora tez çalışmasından türetilmiştir.

2 Dr. Ö̆gr. Üyesi - Karabük Üniversitesi İşletme Fakültesi, fatihguclu@karabuk.edu.tr

ORCID: 0000-0002-1007-4594
} 


\section{Giriş}

İslami finansın uygulama alanlarından birisi de sermaye piyasalarıdır. Konvansiyonel sermaye piyasalarına benzer şekilde hisse senedi piyasaları ve borçlanma piyasaları olarak kategorize edilen İslami sermaye piyasalarının en önemli borçlanma aracı sukuktur. Sukuk her ne kadar fikhi olarak bir borçlanma aracı olarak yapılandırılmamış olsa da uygulamada bu şekilde kullanılmaktadır. İslami hisse senedi piyasaları boyutunda ise İslami hisse senedi endeksleri ve İslami yatırım fonları, İslami hassasiyetlere sahip yatırımcıların ihtiyaçlarına cevap vermektedir.

İslami hisse senedi piyasalarının işleyişi, konvansiyonel emsallerinden farklı değildir. Zira İslami hisse senedi endeksleri ele alınacak olduğunda, söz konusu endekslerde yer alan hisse senetleri belirli filtreleme ölçütleri çerçevesinde konvansiyonel hisse senedi piyasalarında işlem gören hisse senetleri arasından seçilmektedir. Dolayısıyla, tasarruflarını İslami hisse senedi piyasalarında değerlendirmek isteyen bir yatırımc1, tıpk1 konvansiyonel hisse senedi piyasalarına yatırım yapan bir yatırımcı gibi yatırımına ve aldığ1 riske karşıllı belirli bir getiri bekleyecektir. Bu bağlamda İslami hisse senedi piyasalarına yatırımda bulunacak kişilerin, belirsizliğin bir ölçüsü olan oynaklık konusunda bir fikir sahibi olması, yatırımından beklentisini daha sağlıklı bir şekilde oluşturmasına katkı sağlayacaktır.

Modern Portföy Teorisi ve Modern Portföy Teorisini temel alan Sermaye Varlıkları Fiyatlama Modeli (SVFM) bağlamında riskin ölçüsü, varyans ve standart sapmadır. Ancak getiri serilerinin değişen varyans (heteroskedasticity) özelliği göstermesi nedeniyle, riskin ARCH tipi modellerle belirlenmesi daha gerçekçi sonuçlar verebilmektedir. Bu bağlamda çalışmanın amacı, Türkiye, Malezya, A.B.D. ve İngiltere İslami ve konvansiyonel hisse senedi endekslerinin oynaklıklarının tahmin edilmesi ve tahmin edilen oynaklikların hem ülke hem de İslami hisse senedi endeksleri bazında karşılaştırılmasıdır. Çalışmada Türkiye ve bahsi geçen ülkelerin hisse senedi piyasalarının incelenmesinin nedeni, A.B.D.'nin işlem hacmi ve piyasa değeri açısından dünyanın en gelişmiş hisse senedi piyasalarına sahip olması, İngiltere'nin nüfusunun çoğunluğu Müslüman olmayan bir ülke olmasına karşın İslami finans uygulamalarında öncü ülkelerden birisi olması ve Malezya'nın İslami finansta uygulama ve ürün çeşitliliği bağlamında en önde gelen ülkelerden birisi olmasidir. Oynakliklar, ARCH tipi modellerden GARCH, EGARCH ve GJR-GARCH modeller kullanılarak tahmin edilmiştir. Karşılaştırma ise kaldıraç etkisinin varlığı, oynaklıktaki kalıclık etkisi, oynaklık yarılanma süresi, uzun dönem ve kısa dönem oynaklık ölçütlerine göre yapılmıştır.

\section{Teorik Çerçeve}

Konvansiyonel hisse senedi piyasalarında işlem gören hisse senetlerinin tamamı, İslam'ın izin verdiği alanlarda faaliyet gösteren şirketlere ait değildir. Bununla birlikte faaliyet alanı açısından İslami kurallara zıt düşmeyen şirketlerin aktif ve pasiflerinin nerelere yatırıldığ ya da nerelerden elde edildiği, bu şirketlere ait hisse senetlerinin İslami kurallara uygun bir yatırım aracı olma vasfını taşıyı taşımadığını belirleyen hususlardır. Bu bağlamda İslami hisse senedi endeksleri, Müslüman yatırımcıların dini hassasiyetlerini göz önünde bulundurarak konvansiyonel hisse senedi piyasalarında işlem gören hisse senetlerini İslami kurallar baz alınarak oluşturulan filtreleme ölçütleri ile eleyip, bu eleme neticesinde uygun hisse senetlerinden teşkil edilen endekslerdir. İslami hisse senedi endeksleri, çeşitli endeks sağlayıcıları ve borsalar tarafindan 1990’ların sonundan itibaren yayınlanmaya başlamıştır.

İslami hisse senedi endekslerinin filtreleme ölçütleri, temel olarak faaliyet alanı ölçütleri ve finansal ölçütler olmak üzere iki ana kategori altında sınıflandırılabilir. Hisse senedinin ortaklık payını temsil ettiği şirketin faaliyet alanı, İslam'ın yasakladığı; domuz yetiştiriciliği, alkol üretimi ve satış1, tütün üretimi ve satışı, kumar, faiz tabanlı konvansiyonel finansal faaliyetler, vadeli altın ve gümüş alım-satımı, müstehcen içerik barındıran reklamclık ve yayıncılık gibi alanlardan birisinin içerisinde olmamalıdır (Ho vd., 2014: 111). Şirketin kendisi bu alanların birinde faaliyet göstermemekle birlikte, iştirakleri ya da bağlı olduğu holding, İslam'a aykırı alanlardan birinde faaliyet gösteriyor ise şirket İslami hisse endeksi içerisinde yer alamamaktadır (Alhabshi, 1994, s. 7). Faaliyet alanına göre endekste bulunmasında sakınca bulunmayan şirketler, bu kez finansal ölçütlerin filtrelemesine tabi tutulur. Finansal ölçütler, ideal olarak şirketlerin hiçbir şekilde konvansiyonel bankaların vadeli hesaplarında mevduat bulundurma, faizli kredi kullanımı gibi işlemlerde bulunmamalarını gerektirmektedir. Ancak, kuralın bu şekilde işletilmesi halinde geriye çok az şirketin kalacak olması ve bu durumun çeşitlendirme imkânını azaltacağı, dolayısıyla hisse yatırımlarının riskini yükselteceği gibi nedenlerle finansal ölçütler endeks sağlayıcıları tarafından daha esnek bir şekilde uygulanmaktadır (El Khamlichi, Sannajust ve Sarkar, 2014, s. 70). Finansal ölçütler pratikte, şirketin borç/özsermaye oranı, alacak/özsermaye oranı gibi birtakım finansal oranlarının, belirlenen eşik değerlerle 
karşılaştırılması ve oranları eşik değerlerle uyumlu olan şirketlerin endekste kalması biçiminde işlemektedir (Ho vd., 2014, s. 111). Bir şirketin bir kez İslami hisse senedi endeksine girmesi, daima endekste kalacağ1 anlamına gelmemektedir. Endeks sağlayıcıları tarafindan endekste yer alan şirketler belirli dönemlerde tekrar gözden geçirilmekte ve ölçütleri karşılamayan şirketler endeksten çıkarılarak, yerlerine varsa şartları sağlayan diğer şirketler eklenmektedir. Burada temel özellikleri belirtilen endeks kriterleri, her ne kadar benzerlik gösterseler de her endeks sağlayıcı tarafından Şer’i danışma kurullarının verdikleri tavsiyeler doğrultusunda farklı şekillerde uygulanmaktadır.

Hisse senedi piyasalarında oynaklık (volatilite), belirli bir zaman dilimi içerisinde hisse senedi fiyatlarının yukarı veya aşağı yönlü hızlı bir şekilde hareket etmesi olarak tanımlanabilir (Listyaningsih ve Krishnamurti, 2016, s. 110). Bu bağlamda belirsizliğin bir ölçüsü olan oynaklık, risk ile yakından ilişkili bir kavramdır. Dolayısıyla, özellikle yatımcıların alacakları kararlarda, yatırım yapmak istedikleri varlı̆ı̆n ya da piyasanın oynaklığını bilmeleri büyük önem arz etmektedir. Zira, yatırımcıların belirsizlik nedeniyle yatırımlarının getirilerini tahmin etmeleri zorlaşmaktadır (Değirmenci ve Abdioğlu, 2017, s. 105). Bununla birlikte, yüksek oynaklğga sahip piyasalar veya finansal varlıklar daha yüksek getiri sağlama potansiyelini bünyelerinde barındıkları için, riski seven yatırımcılar bu piyasalara yatırım yapmayı tercih edebilmektedir (Romli, Mohamad ve Yusof, 2012, s. 8490). Tersten ifade edilecek olursa, oynaklığın düşük olduğu piyasalarda spekülasyona dayalı olarak kâr elde imkânı düşüktür (Şahin, 2014, s. 123). Oynaklık, yatırımcıların yanı sıra hükümetler, şirket yöneticileri ve ekonomistlerin de ilgi alanına giren ve aldıkları kararlarda kullandıkları bir ölçüttür (Scott, 1991, s. 582).

Geleneksel yaklaşımda, oynaklık yani risk ölçütü olarak standart sapma ve varyans kullanılmaktadır. Ancak zaman serilerinin varyansının zamandan bağımsız olduğunu varsayan bu yaklaşımın aksine, özellikle yüksek frekanslı zaman serilerinin varyanslarının sabit olmadığı, değissen varyans (heteroskedasticity) özelliği gösterdiği bilinmektedir (Yıldız, 2016, s. 85). Buradan hareketle Engle (1982) çalışmasında, zaman serilerinde oynaklık kümelenmesi olarak adlandırllan, oynaklığın yüksek ve düşük olduğu dönemleri saptamış ve bu durumun sebebinin koşullu değişen varyans olduğunu belirlemiştir. Geliştirdiği ARCH (Otoregresif Koşullu Değiş̧en Varyans-Autoregressive Conditional Heteroskedasticity) modeli ile serilerdeki koşullu değişen varyansı modellemiştir (Çiçek, 2010, s. 16). Literatürde oynaklığın tahmin edilmesinde ARCH tipi modeller olarak adlandırilan GARCH, EGARCH, TARCH, GJR-GARCH, NGARCH gibi modeller de sıklıkla kullanılmaktadır.

\section{Literatür Taraması}

İslami hisse senedi piyasalarının oynaklığı ile ilgili literatür, Türkiye dışındaki ülkelerde oldukça genişken, Türkiye'de konuyla ilgili yapılmış çalışmaların sayısı çok azdır. Ayrıca yapılan çalışmalar yalnızca Türkiye'ye odaklanmış, Türkiye İslami hisse senedi piyasasının oynaklığını diğer ülkelerin piyasaları ile karşılaştıran çalışmalara rastlanmamıştır. Bu bölümde, literatürde İslami hisse senedi piyasalarının oynaklı̆̆1 üzerine yapılan çalışmalardan özet olarak bahsedilecektir.

Lean ve Parsva (2012) çalışmalarında, Malezya İslami (FTSE Borsa Malezya Hijrah İslami Endeksi, FTSE Borsa Malezya EMAS İslami Endeksi) ve konvansiyonel (FTSE Borsa Malezya KLCI Endeksi, FTSE Borsa Malezya 100 Endeksi, FTSE Borsa Malezya EMAS Endeksi) hisse senedi endekslerinin performansını ve oynaklığını incelemişlerdir. CAPM analizine göre İslami endeksler daha yüksek getiri ve düşük riske sahiptir. GARCH model kullanılarak yapılan oynaklık analizi ise İslami endekslerin oynaklığının konvansiyonel endekslerden daha düşük olduğunu göstermektedir

Dharani (2012) çalışmasında, 2007-2011 yıllanı için Hindistan İslami (S\&P CNX Nifty İslami Endeksi) ve konvansiyonel (S\&P CNX Nifty Endeksi) hisse senedi endekslerinin performansinı kıyaslamış, kısa uzun dönem ilişkilerini belirlemeye çalışmış ve oynaklıklarını tahmin etmiştir. GARCH ve TGARCH model kullanılarak tahmin edilen oynaklıklara göre İslami endeksin oynaklığının, konvansiyonel endeksten daha düşük olduğu belirlenmiştir.

Abbes (2012) çalışmasında, farklı coğrafyalardan 2002-2012 dönemi için 35 ülkeye ait İslami ve konvansiyonel hisse senedi endeksinin performansını ve endekslerde kaldıraç etkisinin olup olmadığını incelemiştir. Hem ortalama getiriler hem de risk ayarlı performans ölçüm yöntemlerinden Sharpe oranı ile yapılan performans karşılaştırmasında, İslami hisse senedi endeksleri ile konvansiyonel hisse senedi endekslerinin getiri performansı arasında bir farklılık bulunamamıştır. Getirilerle oynaklık arasında asimetrik bir ilişkisinin varlığı anlamına gelen kaldıraç etkisine ise EGARCH model tahmini ile bakılmış ve hem İslami hem de konvansiyonel hisse senedi endekslerinde kaldıraç etkisinin varlığı tespit edilmiştir. 
Sukmana ve Kholid (2012), 2001-2009 dönemi için Cakarta İslami endeksi ile Cakarta Bileşik Endeksinin oynaklıklarını ARCH ve GARCH modelleri ile tahmin edip karşılaştırdıkları çalışmalarında, İslami hisse senedi endeksinin oynaklığının daha düşük olduğu yani söz konusu endekse yatırım yapmanın daha risksiz olduğu sonucuna ulaşmışlardır.

Romli, Mohamad ve Yusof (2012) çalışmalarında, 2007-2010 dönemi için Malezya İslami hisse senedi endeksleri (FTSE Borsa Malezya Hijrah İslami Endeksi, FTSE Borsa Malezya EMAS İslami Endeksi) ve konvansiyonel hisse senedi endeksinin (FTSE Borsa Malezya KLCI Endeksi) oynaklıklarını karşılaştırmışlardır. Oynaklık tahmininde GARCH modelin kullanıldığı çalışmada, İslami hisse senedi endekslerinin oynaklığı, konvansiyonel hisse senedi endeksine göre çok yüksek bulunmuştur.

Hammoudeh, Mensi, Reboredo ve Nguyen (2014) Dow Jones İslami Piyasa Dünya Endeksi ile S\&P ABD, Avrupa ve Asya konvansiyonel hisse senedi endekslerinin 1999-2013 yılları için aralarındaki oynaklık ilişskilerini inceledikleri çalışmalarında, İslami hisse senedi endekslerinin konvansiyonel endekslerle benzer oynaklık karakteristiği gösterdiği sonucuna ulaşmışlardır.

Bousalam ve Hamzaoui (2016), 2013-2014 dönemi için öncelikle Fas hisse senedi endeksi (MASI) içerisindeki hisse senetlerinden Dow Jones, FTSE, S\&P ve MSCI'nin İslami filtreleme ölçütlerini kullanarak, Fas için 4 ayrı İslami senedi endeksi oluşturmuşlardır. Daha sonra oluşturdukları bu endekslerle Fas hisse senedi endeksinin oynaklıklarını tahmin ederek karşılaştırmıştır. Tüm hisse senedi endekslerinin benzer oynaklık davranışı gösterdiği sonucuna ulaşılmıştır.

Listyaningsih ve Krishnamurti (2016) çalışmalarında, 2005-2012 yılları için Cakarta İslami hisse senedi endeksinde yer alan hisse senetleriyle, bu endeksin dışında kalan hisse senetlerinin oynaklıklarını GARCH modeller ile karşıllaştırmışlardır. Çalışma sonucunda Listyaningsih ve Krishnamurti (2014) ile benzer şekilde, Cakarta İslami hisse senedi endeksinde yer alan hisse senetlerinin, diğer hisse senetlerinden daha düşük oynaklığa sahip olduğu sonucuna ulaşmışlardır.

Seçme, Aksoy ve Uysal (2016), 2011-2015 yılları arasında BIST100 Endeksi ve Katıllım 30 endekslerinin performanslarını ve oynaklıklarını inceledikleri çalışmalarında, GARCH ve EGARCH modellerini kullanarak, endekslerin oynaklıklarını tahmin edip, BIST100 Endeksi'nin oynaklığının, Katılım 30 Endeksi'nden daha yüksek olduğu sonucuna ulaşmışlardır.

Hkiri, Hammoudehi Aloui ve Yarovaya (2017) çalışmalarında, 1999-2014 yılları için Asya, Rusya, Arjantin, Brezilya ve ABD konvansiyonel hisse senedi endeksleri ile bu endekslere karşllı gelen İslami hisse senedi endekslerinin oynaklıklarını karşılaştırmışlardır. İslami endekslerin oynaklığının kriz dönemlerinde konvansiyonel endekslerden daha düşük olduğu sonucuna ulaşmışlardır.

Çelik, Kılıç ve Kaya (2017) çalışmalarında, MSCI tarafından oluşturulmuş, Türkiye konvansiyonel ve İslâmî endekslerinin hem volatilite kalıcllı̆ı hem de half-life ölçütü bağlamında değerlendirildiği çalışmalarında GARCH (1,1) modelini kullanmışlardır. Çalışma sonucunda, İslami ve konvansiyonel endekslerin volatilite kalıcıllğı ve half-life ölçütü açısından benzer yapıya sahip olduğu gözlenmiştir.

Hatipoğlu ve Sekmen (2018), USD döviz kuru, Ekonomik ve Politik Belirsizlikler Endeksi ve Oynaklık Endeksi'nin (VIX) MSCI Dünya İslam Borsa Endeksi'ne olan etkisini inceledikleri çalışmalarında, Amerikan dolarının dünyada değer kazanması ile İslami borsaların volatilitesinin azaldığı, değer kaybetmesi ile İslami borsalarda volatilitenin arttığı sonucuna ulaşmışlardır.

Fadel ve Al-Ajmi (2019) çalışmalarında, Kuveyt Borsası'nda işlem gören İslami ve geleneksel hisse senetlerinin arasındaki işlem hacmi ve oynaklık ilişkilerini incelemişlerdir. Çalışmanın sonuçlarına göre İslami ve geleneksel hisse senetlerinin işlem hacimleri ve oynaklıkları arasında bir ilişkiye rastlanmamışırı.

Literatür taraması ve çalışmanın amacı doğrultusunda, çalışmada şu hipotezler test edilecektir;

H1: Türkiye İslami hisse senedi endeksinin oynaklığı ile konvansiyonel hisse senedi endeksinin oynaklığı arasında önemli bir farklılık yoktur.

H2: A.B.D. İslami hisse senedi endeksinin oynaklığ1 ile konvansiyonel hisse senedi endeksinin oynaklı̆̆ arasında önemli bir farklılık yoktur.

H3: İngiltere İslami hisse senedi endeksinin oynakllğı ile konvansiyonel hisse senedi endeksinin oynaklı̆̆ arasında önemli bir farklılık yoktur. 
H4: Malezya İslami hisse senedi endeksinin oynaklı̆̆ ile konvansiyonel hisse senedi endeksinin oynaklı̆̆ı arasında önemli bir farklılık yoktur.

H5: Türkiye, A.B.D., İngiltere ve Malezya İslami hisse senedi endekslerinin oynaklıkları arasında önemli bir farklilık yoktur.

\section{Yöntem}

\section{Evren-Örneklem, Veri Seti}

Çalışmada Türkiye, A.B.D., İngiltere ve Malezya konvansiyonel hisse senedi endeksleri için sırasıyla Borsa İstanbul 100 Endeksi (BIST100), Dow Jones Endüstri Ortalama Endeksi (DJIND), Financial Times Hisse Senedi 100 Endeksi (FTSE100), FTSE Malezya Borsas1 KLCI Endeksi (KLCI), İslami hisse senedi endeksleri için ise Katılım 30 Endeksi (KAT30), Dow Jones İslami Piyasa A.B.D. Endeksi (DJISUS), Morgan Stanley Capital International İngiltere İslami Endeksi (MSCIUKIS) ve FTSE Malezya Borsas1 Hijrah Şer’i Endeksi’nin (HIJRAH) günlük kapanış fiyatları kullanılmıştır. Örneklem dönemi tüm endeksler için 06.01.2011 ile 28.02.2018 tarihleri arası olarak belirlenmiştir. Başlangıç tarihi olarak 06.01.2011 tarihinin belirlenmesinin nedeni, Türkiye İslami hisse senedi endeksi KAT30 endeksinin, bu tarih itibariyle yayınlanmaya başlanmış olmasıdır. Çalışmada kullanılan tüm veriler, Thomson Reuters Datastream veri tabanından elde edilmiştir.

Oynaklıkların tahmin edilmesinde, endekslerin günlük kapanış değerleri üzerinden hesaplanan günlük getiri serileri kullanılmıştır. Getiri serileri şu formül vasıtasıyla hesaplanmışıı;

$$
\mathrm{R}_{\mathrm{i}, \mathrm{t}}=\ln \left[\frac{\mathrm{P}_{\mathrm{i}, \mathrm{t}}}{\mathrm{P}_{\mathrm{i}, \mathrm{t}-\mathrm{t}}}\right]
$$

$$
\begin{aligned}
& \text { Burada; } \mathrm{R}_{\mathrm{i}, \mathrm{t}} \text {, gününde i endeksinin getirisini, } \\
& \mathrm{P}_{\mathrm{i}, \mathrm{t}} \text {, } \text { gününde } \mathrm{i} \text { endeksinin kapanış fiyatını, } \\
& \mathrm{P}_{\mathrm{i}, \mathrm{t}-1} \text { ise } \mathrm{t}-1 \text { gününde } \mathrm{i} \text { endeksinin kapanıs fiyatını ifade etmektedir. }
\end{aligned}
$$

\section{GARCH Model}

Engle (1982) çalışmasında, zaman serilerinde oynaklık kümelenmesi olarak adlandırılan oynaklı̆̆ın yüksek ve düşük olduğu dönemleri saptamış ve bu durumun sebebin koşullu değiş̧en varyans olduğunu belirlemiştir. Geliştirdiği ARCH modeli ile serilerdeki koşullu değişen varyansı modellemiştir (Çiçek, 2010, s. 16). ARCH modelin matematiksel ifadesi şu şekildedir;

$$
\mathrm{r}_{\mathrm{t}}=\mu+\sum_{\mathrm{i}=1}^{\mathrm{p}} \varphi_{\mathrm{i}} \mathrm{r}_{\mathrm{t}-\mathrm{i}}+\sum_{\mathrm{i}=1}^{\mathrm{q}} \theta_{\mathrm{i}} \varepsilon_{\mathrm{t}-\mathrm{i}}+\varepsilon_{\mathrm{t}}
$$

$$
\sigma_{\mathrm{t}}^{2}=\omega+\sum_{\mathrm{i}=1}^{\mathrm{p}} \alpha_{\mathrm{i}} \varepsilon_{\mathrm{t}-\mathrm{i}}^{2}
$$

Burada, Denklem 2 otoregresif hareketli ortalama denklemini [ARMA (p,q)] ifade etmektedir. $\varepsilon_{\mathrm{t}}$, koşullu varyans $\sigma_{\mathrm{t}}^{2}$ ile birlikte değişen varyanslı hata terimini göstermektedir. Denklem 3 ise ARCH (p) şeklinde ifade edilen koşullu varyans denklemini göstermektedir.

ARCH modelin çok katı kısıtlara sahip olması, olası varyans davranışının nedenlerini açıklamaması, büyük şoklara yavaş tepki vermesi ve bu nedenle oynakliğı olduğundan daha büyük tahmin etmesi gibi zayıflıkları nedeniyle, Bollerslev (1986) GARCH (Genelleştirilmiş Otoregresif Koşullu Değişen Varyans Generalized ARCH) modelini geliştirmiştir (Kayalıdere, 2013, s. 41). Söz konusu model, finans literatüründe oynaklık tahminlerinde en sık kullanılan modellerden bir tanesidir (Korkmaz ve Çevik, 2009a, s. 29). GARCH modelin matematiksel gösterimi şu şekildedir;

(4)

$$
r_{t}=\mu+\sum_{i=1}^{p} \varphi_{i} r_{t-i}+\sum_{i=1}^{q} \theta_{i} \varepsilon_{t-i}+\varepsilon_{t}
$$

$$
\sigma_{\mathrm{t}}^{2}=\omega+\sum_{\mathrm{i}=1}^{\mathrm{p}} \alpha_{\mathrm{i}} \varepsilon_{\mathrm{t}-\mathrm{i}}^{2}+\sum_{\mathrm{i}=1}^{\mathrm{q}} \beta_{\mathrm{i}} \sigma_{\mathrm{t}-\mathrm{i}}^{2}
$$


Denklem 4 ARMA (p,q) şeklinde belirlenen koşulsuz otoregresif hareketli ortalama denklemini ifade etmektedir. $\varepsilon_{\mathrm{t}}$, koşullu varyans $\sigma_{\mathrm{t}}^{2}$ ile birlikte değişen varyanslı hata terimini göstermektedir. Denklem 5 , GARCH (p,q) koşullu varyans denklemini ifade etmektedir. p, ARCH terimi sayısını, q ise GARCH terimi sayısını göstermektedir. GARCH modelin birtakım kısıtları bulunmaktadır. Bunlar; $\mathrm{p} \geq 0, \mathrm{q}>0, \omega>0, \alpha_{i}$ $\geq 0, \beta_{i} \geq 0$ ve $\alpha_{i}+\beta_{i}<1$ kisıtlarıdır (Çevik ve Pekkaya, 2007, s. 57; Kayalıdere, 2013, s. 47).

GARCH modeller, pozitif ve negatif hata terimlerinin oynaklık üzerinde simetrik etkide bulunduğunu varsaymaktadır. Ancak özellikle finansal zaman serilerinde iyi ve kötü haberler (şoklar) oynaklık üzerinde aynı etkiyi yapmamakta, oynaklığı asimetrik olarak etkilemektedir. Kaldıraç etkisi olarak adlandırılan ve kötü şokların, oynaklığı iyi şoklardan daha fazla etkilemesi olarak ifade edilen bu durumu modellemek için literatürde EGARCH ve GJR-GARCH olarak bilinen modeller kullanılmaktadır (Çiçek, 2010, s. 16). Bu nedenle çalışmada oynaklıklar, GARCH modelin yanı sıra bahsi geçen modeller kullanılarak da tahmin edilmiştir.

\section{EGARCH Model}

Finansal varlık getirilerinin kötü şoklardan iyi şoklara nazaran daha fazla etkilenmesi, literatürde kaldıraç etkisi olarak adlandırılmaktadır. Oynaklık üzerindeki asimetrik etki olarak da isimlendirilen bu durum, ARCH-GARCH modeller kullanılarak modellenememektedir. Nelson (1991) çalışmasında, kaldıraç etkisini modellemeye imkân veren EGARCH (Üstel GARCH - Exponential GARCH) modelini geliştirmiştir. EGARCH modelin matematiksel gösterimi şu şekildedir;

$$
r_{t}=\mu+\sum_{i=1}^{p} \varphi_{i} r_{t-i}+\sum_{i=1}^{q} \theta_{i} \varepsilon_{t-i}+\varepsilon_{t}
$$

$$
\ln \sigma_{t}^{2}=\omega+\sum_{i=1}^{p} \alpha_{i}\left|\frac{\varepsilon_{t-i}}{\sigma_{t-i}}\right|+\sum_{i=1}^{\mathrm{q}} \beta_{i} \ln \sigma_{t-i}^{2}+\sum_{i=1}^{r} \gamma_{i}\left|\frac{\varepsilon_{t-i}}{\sigma_{t-i}}\right|
$$

Denklem 6, GARCH modelde olduğu gibi ARMA (p,q) şeklinde belirlenen koşulsuz otoregresif hareketli ortalama denklemini ifade etmektedir. Denklem 7 ise EGARCH (p,q) koşullu varyans denklemini ifade etmektedir. p, ARCH terimi sayısını, q ise GARCH terimi sayısını göstermektedir. Buradaki $\alpha_{i}$ parametresi ARCH etkisini, $\beta_{i}$ parametresi ise volatilitenin kalıcılığını ölçen parametrelerdir. Denklem 7'de yer alan $\gamma_{i}$ parametresi, kaldıraç etkisi ölçen asimetri parametresidir. Volatilite ile getiri arasında ters yönlü bir ilişki olduğu için $\gamma_{i}$ parametresinin negatif olması beklenir. $\gamma_{i}$ parametresinin istatistiksel olarak anlamlı olması, kaldıraç etkisinin varlığını göstermektedir. (Çiçek, 2010; Kayalıdere, 2013, s. 60).

EGARCH modelin, GARCH modele göre kaldıraç etkisinin modellenmesine imkân vermesinin yanında, ilave birtakım üstünlükleri bulunmaktadır. EGARCH modelde koşullu varyans logaritmik formda modellendiği için GARCH modeldeki parametrelerin negatif olmama kısıdı ortadan kalkmaktadır. Ayrıca hata teriminin geçmiş değeri yerine standardize hataların kullanılması sayesinde, şokların kalıcılı̆̆1 ve büyüklüğü ile ilgili daha doğal açıklama yapma imkânı sağlamaktadır (Korkmaz ve Çevik, 2009a, s. 29).

\section{GJR-GARCH Model}

Oynaklık üzerindeki kaldıraç etkisini modellemeye imkân veren bir diğer GARCH tipi model, GJRGARCH (Eşik GARCH) modeldir. Glosten, Jaganathan ve Runkle (1993) tarafindan geliştirilen modelin matematiksel ifadesi şu şekildedir;

$$
\mathrm{r}_{\mathrm{t}}=\mu+\sum_{\mathrm{i}=1}^{\mathrm{p}} \varphi_{\mathrm{i}} \mathrm{r}_{\mathrm{t}-\mathrm{i}}+\sum_{\mathrm{i}=1}^{\mathrm{q}} \theta_{\mathrm{i}} \varepsilon_{\mathrm{t}-\mathrm{i}}+\varepsilon_{\mathrm{t}}
$$

$$
\sigma_{\mathrm{t}}^{2}=\omega+\sum_{\mathrm{i}=1}^{\mathrm{p}} \alpha_{\mathrm{i}} \varepsilon_{\mathrm{t}-\mathrm{i}}^{2}+\sum_{\mathrm{i}=1}^{\mathrm{q}} \beta_{\mathrm{i}} \sigma_{\mathrm{t}-\mathrm{i}}^{2}+\sum_{\mathrm{i}=1}^{\mathrm{r}} \gamma_{\mathrm{i}} \varepsilon_{\mathrm{t}-\mathrm{i}}^{2} \mathrm{I}_{\mathrm{t}-\mathrm{i}}
$$

Denklem 8 GARCH ve EGARCH modelde olduğu gibi ARMA (p,q) şeklinde belirlenen koşulsuz otoregresif hareketli ortalama denklemini ifade etmektedir. Denklem 9, GJR-GARCH (p,q) koşullu 
varyans denklemini ifade etmektedir. p, ARCH terimi sayısını, q ise GARCH terimi sayısını belirtmektedir. GJR-GARCH modelde iyi ve kötü şokların etkisi farklı olmakla birlikte $\alpha_{i}$ iyi şokların, $\alpha_{i}+\gamma_{i}$ kötü şokların etkisini göstermektedir. $\gamma_{i}>0$ ise kötü şoklar volatiliteyi artırıyor demektir. Başka bir ifadeyle, kaldıraç etkisi söz konusudur (Korkmaz ve Çevik, 2009b, s. 94). GJR-GARCH modelde, EGARCH modelin aksine GARCH modelde olduğu gibi parametrelerin negatif olmama kısıdı bulunmaktadır. Ayrıca yine GARCH modelde olduğu gibi sürecin durağan olduğunu ifade edebilmek için $\alpha_{i}+\beta_{i}<1$ koşulunun sağlanması gerekmektedir (Shahzad, Ferrer, Ballester ve Umar, 2017, s. 24).

\section{Endekslerin Oynaklıklarının Karşılaştırılması}

Çalışma kapsamında incelenen hisse senedi endeksleri için en uygun oynaklık tahmin modellerinin belirlenmesinin ardından, tahmin edilen oynaklıklar birtakım ölçütlere göre kıyaslanmıştır. Kullanılan ölçütler şu şekildedir:

Kaldıraç Etkisi: Tahmin edilen oynaklık modellerinde kaldıraç etkisi, $\gamma_{i}$ parametresi ile ölçülmektedir. Oynaklıkları EGARCH model ile tahmin edilen endeksler için $\gamma_{i}$ parametresi (negatif bir değer alması beklenir) daha küçük olan endekslerin oynaklığı, kötü şoklara daha duyarlıdır. Oynaklıkları GJR-GARCH model ile tahmin edilen endeksler için ise $\gamma_{i}$ parametresi (pozitif bir değer alması beklenir) daha büyük olan endekslerin oynaklığı, kötü şoklara daha duyarlıdır (Bousalam ve Hamzaoui, 2016, s. 16).

Oynaklıktaki Kalıcılık Etkisi ve Oynaklık Yarılanma Süresi: Koşullu varyansa etki eden şokların oynaklık üzerindeki etkisinin kalıcılığı olarak tanımlanan oynaklık kalıcılığı, ARCH etkisini gösteren $\alpha_{i}$ ve GARCH etkisini gösteren $\beta_{i}$ parametrelerinin toplamı ile ölçülür (Li, 2012, s. 1809). $\alpha_{i}+\beta_{i}$ toplamı 1'den ne kadar küçükse oynaklık kalıcılık etkisi de o denli düşüktür. Başka bir ifadeyle, herhangi bir şok neticesinde artan oynaklık, kalıcılık etkisi düşük olduğu için belirli bir zaman zarfindan sonra sönümlenir. Yani, getirilerde meydana gelen değişimler oynaklığı yükseltmekte ancak oynaklık kalıcılığının düşük olması nedeniyle, oynaklık değişimi bir süre sonra normal düzeye inmektedir (Kayalıdere, 2013, s. 48).

Oynaklık yarılanma süresi (half-life volatility) ise piyasalarda oluşan bir şok sebebiyle meydana gelen oynaklığın eski seviyesine dönüş periyodudur. $\alpha_{i}+\beta_{i}$ toplamı 1'e yaklaştıkça, oynaklık şokunun yarılanma süresi de artacaktır. (Kayalıdere, 2013, s. 11). Oynaklık yarılanma süresi şu formül vasıtasıyla hesaplanabilir;

$$
\text { Oynaklık Yarılanma Süresi }=\frac{\ln (0,5)}{\ln \left(\alpha_{\mathrm{i}}+\beta_{\mathrm{i}}\right)}
$$

Uzun Dönem Oynaklık ve Günlük Oynaklık: Oynaklığın tahmin edildiği dönem için ortalama bir oynaklık değeri hesaplamak mümkündür. Uzun dönem oynaklık olarak adlandırılan bu değer Denklem 16'daki formül vasıtasıyla hesaplanabilir. Bu denklem vasıtasıyla hesaplanan değerin karekökü alındığında ise günlük oynaklık elde edilmektedir (Şahin, 2014, s. 50).

$$
\begin{aligned}
& \text { Uzun Dönem Oynaklık }=\frac{\omega}{1-\alpha_{\mathrm{i}}-\beta_{\mathrm{i}}} \\
& \text { Günlük Oynaklık }=\sqrt{\frac{\omega}{1-\alpha_{\mathrm{i}}-\beta_{\mathrm{i}}}}
\end{aligned}
$$

etmektedir.

\section{Bulgular}

Çalışma kapsamında incelenen İslami ve konvansiyonel hisse senetlerine ait tanımlayıcı istatistikler Tablo 1'de verilmiştir.
10.,11. ve 12. denklemlerde;

$\omega$, Modelin sabit terimini,

$\alpha_{\mathrm{i}}, \mathrm{ARCH}$ parametresini,

$\beta_{i}$, GARCH parametresini ifade 
İslami ve Konvansiyonel Hisse Senedi Endekslerinin Oynaklıkları Üzerine Bir İnceleme

Tablo 1. Getiri Serilerine Ait Tanmlaync Istatistikler

\begin{tabular}{|c|c|c|c|c|c|c|c|c|}
\hline \multirow{2}{*}{$\frac{\text { Ülke }}{\text { Endeks }}$} & \multicolumn{2}{|c|}{ Türkiye } & \multicolumn{2}{|c|}{ A.B.D. } & \multicolumn{2}{|c|}{ İngiltere } & \multicolumn{2}{|c|}{ Malezya } \\
\hline & BIST100 & KAT30 & DJIND & DJISUS & FTSE100 & MSCIUKIS & KLCI & HIJRAH \\
\hline Gözlem S. & 1802 & 1802 & 1797 & 1797 & 1806 & 1806 & 1753 & 1753 \\
\hline Ortalama & 0,000300 & 0,000405 & 0,000423 & 0,000409 & 0,000102 & 0,000071 & 0,000096 & 0,000179 \\
\hline Std. Sapma & 0,014072 & 0,011840 & 0,008575 & 0,009250 & 0,009424 & 0,010120 & 0,005625 & 0,005751 \\
\hline Çarpıklık & $-0,5856$ & $-0,8250$ & $-0,5928$ & $-0,5143$ & $-0,2242$ & $-0,1869$ & $-0,2882$ & $-0,1186$ \\
\hline Basıklık & 7,2764 & 10,072 & 7,7509 & 7,6484 & 5,5379 & 5,2295 & 5,9281 & 6,1823 \\
\hline J-B Testi & $1476,106^{*}$ & $3959,952^{*}$ & $1795,256^{*}$ & $1697,086^{*}$ & 499,796* & $384,576^{*}$ & $650,513^{*}$ & $743,825^{*}$ \\
\hline ARCH-LM(5) & $15,58226^{*}$ & $27,06271^{*}$ & $85,70321 *$ & $81,67531^{*}$ & $61,01274^{*}$ & $51,41943^{*}$ & $33,20667^{*}$ & $24,18936 *$ \\
\hline $\mathrm{Q}(42)$ & 33,407 & 28,212 & 38,976 & 42,670 & 28,357 & 25,092 & 33,768 & 19,468 \\
\hline $\mathrm{Q}_{\mathrm{s}}(42)$ & 237,84 & 247,36 & 1269,5 & 1441,5 & 1529,7 & 1279,9 & 703,28 & 593,23 \\
\hline ADF İst. & $-23,1723 *$ & $-23,3229 *$ & $-21,3949 *$ & $-9,3939 *$ & $-23,4124^{*}$ & $-22,3873^{*}$ & $-23,9537 *$ & $-23,4948^{*}$ \\
\hline PP İst. & $-43,6934^{*}$ & $-43,2277^{*}$ & $-44,5373^{*}$ & $-44,2484 *$ & $-41,7790^{*}$ & $-40,7459 *$ & $-38,3448^{*}$ & $-38,2220^{*}$ \\
\hline
\end{tabular}

Not: * işareti, Jarque-Bera (J-B) normallik testi için \%1 önem düzeyinde "seri normal dağılımlıdır" sıfır hipotezinin reddedildiğini, ARCH-LM testi için \%1 önem düzeyinde "hata terimlerinde ARCH etkisi yoktur" sıfir hipotezinin reddedildiğini, ADF ve PP birim kök testleri için \%1 önem düzeyinde "seriler birim kök içermektedir" sıfır hipotezinin reddedildiğini göstermektedir. Q(.) ve $\mathrm{Q}_{\mathrm{s}}($.$) hata terimleri ve hata terimlerinin kareleri için Ljung-Box otokorelasyon testini ifade etmektedir.$

Tablo 1'de, örneklem dönemi içerisinde tüm endekslerin pozitif ortalama getiri sağladığı görülmektedir. Tüm endeksler arasında en yüksek ortalama getiri sağlayan endeks, DJIND'dir. En düşük ortalama getiri ise MSCIUKIS'e aittir. Türkiye ve Malezya İslami hisse senedi endeksleri konvansiyonel endekslerden daha yüksek ortalama getiri sağlarken, A.B.D. ve İngiltere'de durum tersidir. Riskin bir ölçüsü olan standart sapma değeri en yüksek olan endeks BIST100, en düşük standart sapma değerine sahip endeks ise KLCI endeksidir. İslami hisse senedi endekslerinden yalnızca Türkiye İslami hisse senedi endeksi KAT30'un standart sapması, karşıllk gelen konvansiyonel endeksten düşüktür. Diğer tüm ülkelerde konvansiyonel hisse senedi endekslerinin standart sapmas1, İslami hisse senedi endekslerinden düşüktür. Jarque-Bera testi sonuçlarına göre endeks getiri serilerinin hiçbiri normal dağılım göstermemektedir. Basıklık değerlerinin tüm getiri serileri için 3’ten büyük olması, dağılımların kalın kuyruklu olduğu anlamına gelmektedir. Çarpıklık değerlerinin negatif olması ise tüm getiri serilerinin sola çarpık olduğunu göstermektedir. Hem ADF hem de PP birim kök testlerinin sonuçlarına göre, tüm seriler düzey değerlerde durağandır. 5 gecikme için hesaplanan ARCH-LM testi $\mathrm{F}$ istatistikleri ve olasılık değerlerine göre, tüm serilerin ortalama denklemlerinden elde edilen hata terimlerinde $\mathrm{ARCH}$ etkisinin varlığ1 saptanmıştır. Dolayısıyla incelenen endekslerin oynaklıkları, GARCH, EGARCH ve GJR-GARCH modeller kullanılarak tahmin edilebilir.

\section{Oynaklıkların Farklı Modellerle Tahmin Edilmesi}

Oynaklık tahminin ilk adımı, ARMA (p,q) şeklinde tanımlanan ortalama denkleminin tahmin edilmesidir. Çalışma kapsamında incelenen serilerin en uygun AR ve MA yapıları, Akaike bilgi kriteri (AIC) ve varsayımsal testlerin (hata terimlerinin otokorelasyonsuz olması) sonuçlarına göre belirlenmiştir. $\mathrm{p}=0,1, \ldots, 5$ ve $\mathrm{q}=0,1, \ldots, 5$ kombinasyonları ile oluşturulan modeller arasından en düşük AIC değerine sahip olan ve hata terimlerinde otokorelasyon sorunu bulunmayan modellere, en uygun ARMA yapilar1 olarak karar verilmiştir. Bu bağlamda en uygun ARMA yapıları BIST100 için ARMA (3,5), KAT30 için ARMA (5,5), DJIND için ARMA (4,4), DJISUS için ARMA (5,5), FTSE100 için ARMA (5,1), MSCIUKIS için ARMA (3,4), KLCI için ARMA $(4,3)$ ve HIJRAH için ARMA $(5,2)$ olarak belirlenmiştir.

Oynaklıklar, GARCH model ile kaldıraç etkisini göz önünde bulunduran EGARCH ve GJR-GARCH modeller kullanılarak tahmin edilmiştir. Bu kapsamda, GARCH (1,1), GARCH $(1,2)$, GARCH $(2,1)$, GARCH (2,2), EGARCH (1,1), EGARCH (1,2), EGARCH (2,1), EGARCH (2,2), GJR-GARCH $(1,1)$, GJR-GARCH $(1,2)$, GJR-GARCH $(2,1)$ ve GJR-GARCH $(2,2)$ modelleri test edilmiş, bu modeller arasından en yüksek log-olasılık ve en düşük bilgi kriterleri değerlerine sahip olan $\operatorname{GARCH}(1,1)$, EGARCH $(1,1)$ ve GJR-GARCH $(1,1)$ modelleri en uygun modeller olarak belirlenmiștir. Daha sonra her 
bir endeks getiri serisi için GARCH $(1,1)$, EGARCH $(1,1)$ ve GJR-GARCH $(1,1)$ modelleri arasından seçim, öncelikle model kısıtlarını sağlayan ve modellerden elde edilen hata terimlerinde varsayımsal bir sorun tespit edilmeyen tahminler içerisinden yine bilgi kriterleri ve modellerin log-olasılık değerlerine göre yapılmıştır. Bilgi kriterleri değerleri en küçük ve log-olasılık değerleri en yüksek olan model ilgili endeks için oynaklık tahmininde kullanılacak model olarak tercih edilmiştir. Modellerden elde edilen hata terimlerinin normal dağılım gösterip göstermediği Jarque-Bera testi ile araştırılmış, normal dağılım göstermeyen durumlarda modeller, genelleştirilmiş hata dağlımı (GED) kullanılarak tahmin edilmiştir.

Tablo 2. GARCH (1,1) Modeli ile Oynakllk Tahmini Sonuclar

\begin{tabular}{|c|c|c|c|c|c|c|c|c|}
\hline & \multicolumn{2}{|c|}{ Türkiye } & \multicolumn{2}{|c|}{ A.B.D. } & \multicolumn{2}{|c|}{ İngiltere } & \multicolumn{2}{|c|}{ Malezya } \\
\hline & BIST100 & KAT30 & DJIND & DJISUS & FTSE100 & MSCIUKIS & KLCI & HIJRAH \\
\hline \multicolumn{9}{|c|}{ Ortalama Denklemi } \\
\hline Sabit & $0,0008^{*}$ & $0,0009 *$ & $0,0007^{*}$ & $0,0007^{*}$ & $0,0004 *$ & $-0,0003 * * *$ & $0,0002^{*}$ & $0,0002^{* *}$ \\
\hline $\operatorname{AR}(1)$ & $-0,2423$ & $-0,1627$ & $-0,2574$ & $-0,1563$ & $0,9631 *$ & $-0,1290$ & $0,1172^{*}$ & $-0,1341$ \\
\hline $\mathrm{AR}(2)$ & 0,1362 & $-0,1434$ & 0,1046 & 0,0215 & $-0,0369$ & $-0,6696^{*}$ & $-0,1353^{*}$ & $0,6517 *$ \\
\hline $\operatorname{AR}(3)$ & $-0,586 * * *$ & 0,0301 & $0,5308^{* *}$ & $0,3988^{*}$ & 0,0480 & $-0,5625$ & $0,9409 *$ & $-0,0529$ \\
\hline $\mathrm{AR}(4)$ & & $-0,3815^{*}$ & 0,4418 & 0,6884 & $-0,065^{* * *}$ & & $-0,0633^{*}$ & $-0,0673^{*}$ \\
\hline $\operatorname{AR}(5)$ & & $-0,7703^{*}$ & & $-0,1676$ & 0,0276 & & & 0,0051 \\
\hline $\mathrm{MA}(1)$ & 0,2153 & 0,1614 & 0,2032 & 0,1023 & $-0,9684^{*}$ & 0,1673 & $-0,058 * * *$ & 0,1849 \\
\hline $\mathrm{MA}(2)$ & $-0,1229$ & 0,1749 & $-0,1153$ & $-0,0377$ & & $0,6608 *$ & $0,1246^{*}$ & $-0,6131 * *$ \\
\hline $\mathrm{MA}(3)$ & $0,6028^{*}$ & $-0,0234$ & $-0,5215^{* *}$ & $-0,4347^{*}$ & & 0,6126 & $-0,9540 *$ & \\
\hline $\mathrm{MA}(4)$ & $-0,0007$ & $0,3953^{*}$ & $-0,4438$ & $-0,6950$ & & $-0,0018$ & & \\
\hline $\mathrm{MA}(5)$ & 0,0199 & $0,7642 *$ & & 0,1704 & & & & \\
\hline \multicolumn{9}{|c|}{ Varyans Denklemi } \\
\hline$\omega$ & $0,0000^{*}$ & $0,0000^{*}$ & $0,0000^{*}$ & $0,0000^{*}$ & $0,0000^{*}$ & $0,0000^{*}$ & $0,0000^{*}$ & $0,0000^{*}$ \\
\hline$\alpha_{1}$ & $0,0563^{*}$ & $0,1008^{*}$ & $0,1911 *$ & $0,1725^{*}$ & $0,1329 *$ & $0,1079 *$ & $0,1080^{*}$ & $0,1056^{*}$ \\
\hline$\beta_{1}$ & $0,9154 *$ & $0,8317^{*}$ & $0,7731 *$ & $0,7973 *$ & $0,8348^{*}$ & $0,8600^{*}$ & $0,8598^{*}$ & $0,8564 *$ \\
\hline$\nu$ & $1,3207^{*}$ & $1,2528 *$ & $1,2703^{*}$ & $1,2616^{*}$ & $1,3887^{*}$ & $1,4680^{*}$ & $1,3636^{*}$ & $1,2470 *$ \\
\hline \multicolumn{9}{|c|}{ Varsayımsal Testler } \\
\hline $\mathrm{LM}(5)$ & $\begin{array}{l}1,5150 \\
{[0,182]}\end{array}$ & $\begin{array}{l}1,7034 \\
{[0,130]}\end{array}$ & $\begin{array}{l}0,8902 \\
{[0,487]}\end{array}$ & $\begin{array}{l}0,4790 \\
{[0,792]}\end{array}$ & $\begin{array}{l}0.0923 \\
{[0,993]}\end{array}$ & $\begin{array}{l}0,7518 \\
{[0,585]}\end{array}$ & $\begin{array}{l}0.9203 \\
{[0,467]}\end{array}$ & $\begin{array}{l}0,3451 \\
{[0,886]}\end{array}$ \\
\hline $\mathrm{Q}(42)$ & $\begin{array}{l}39,975 \\
{[0,222]}\end{array}$ & $\begin{array}{l}33,175 \\
{[0,410]}\end{array}$ & $\begin{array}{l}49,526 \\
{[0,062]}\end{array}$ & $\begin{array}{l}44,971 \\
{[0,064]}\end{array}$ & $\begin{array}{l}35,102 \\
{[0,511]}\end{array}$ & $\begin{array}{l}37,302 \\
{[0,364]}\end{array}$ & $\begin{array}{l}30,155 \\
{[0,701]}\end{array}$ & $\begin{array}{l}24,421 \\
{[0,910]}\end{array}$ \\
\hline $\mathrm{Q}_{\mathrm{s}}(42)$ & $\begin{array}{l}31,760 \\
{[0,875]}\end{array}$ & $\begin{array}{l}27,673 \\
{[0,957]}\end{array}$ & $\begin{array}{l}25,007 \\
{[0,983]}\end{array}$ & $\begin{array}{l}26,870 \\
{[0,966]}\end{array}$ & $\begin{array}{l}41,449 \\
{[0,495]}\end{array}$ & $\begin{array}{l}36,410 \\
{[0,714]}\end{array}$ & $\begin{array}{l}41,729 \\
{[0,483]}\end{array}$ & $\begin{array}{r}34,631 \\
{[0,783]}\end{array}$ \\
\hline \multicolumn{9}{|c|}{ Log-olasıllk ve Bilgi Kriteri Değerleri } \\
\hline log-ol. & 5253,30 & 5618,57 & 6326,73 & 6182,05 & 6094,40 & 5922,38 & 6787,93 & 6744,97 \\
\hline AIC & $-5,8258$ & $-6,2366$ & $-7,0426$ & $-6,8829$ & $-6,7556$ & $-6,5562$ & $-7,7483$ & $-7,7037$ \\
\hline SIC & $-5,7861$ & $-6,1907$ & $-7,0028$ & $-6,8369$ & $-6,7220$ & $-6,5196$ & $-7,7108$ & $-7,6660$ \\
\hline HQ & $-5,8111$ & $-6,2196$ & $-7,0279$ & $-6,8659$ & $-6,7432$ & $-6,5427$ & $-7,7345$ & $-7,6897$ \\
\hline
\end{tabular}

Not: *,** ve *** işaretleri sırasıyla $\% 1, \% 5$ ve $\% 10$ önem düzeylerinde ilgili değişkenin anlamlı olduğunu, $\nu$, GED dağılım parametre tahminini, $\mathrm{LM}($.$) ARCH testini, \mathrm{Q}($.$) ve \mathrm{Q}_{\mathrm{s}}($.$) hata terimleri ve hata terimlerinin kareleri için Ljung-Box otokorelasyon$ testini ifade etmektedir. Köşeli parantez içerisindeki değerler ilgili test istatistiğinin olasılık değerlerini göstermektedir.

Tablo 2'deki, GARCH $(1,1)$ modeli tahmin sonuçlarnna göre, tüm endeksler için $\omega, \alpha_{1}$ ve $\beta_{1}$ parametreleri pozitif ve istatistiksel olarak \%1 önem düzeyinde anlamlı olarak tahmin edilmiştir. $\alpha_{i}+\beta_{i}$ toplamlar1 da yine tüm endeksler için 1'den küçük bulunmuştur. Söz konusu sonuçlar, tüm endekslerin oynaklık tahminleri için GARCH modelin kısıtlarının sağlandığını göstermektedir. GED parametresi (v) tüm endeksler için \%1 önem düzeyinde anlamlı ve 2'den küçük bulunmuştur. Bu sonuç hata terimlerinin dağılımının kalın kuyruk özelliği gösterdiğini belirtmektedir. Varsayımsal testler incelendiğinde, ARCH-LM testi sonuçlarına göre tüm endekslerin oynaklık tahmin modellerinden elde edilen hata terimlerinde ARCH etkisinin DJIND endeksi dışında \%1 önem düzeyinde ortadan kalktığı görülmektedir. DJIND endeksinin oynaklık tahmin modelinden elde edilen hata terimlerinde ise $\% 5$ önem düzeyinde ARCH etkisi yoktur. Otokorelasyon testi sonuçlarına göre hiçbir endeksin oynaklık tahmin modellerinden elde edilen hata 
terimlerinde otokorelasyon sorunu bulunmamaktadır. Yine tüm endeksler için hata terimlerinin karelerinde otokorelasyon problemi görülmemektedir.

Tablo 3. EGARCH (1,1) Modeli ile Oynakllk Tahmini Sonuclar

\begin{tabular}{|c|c|c|c|c|c|c|c|c|}
\hline & \multicolumn{2}{|c|}{ Türkiye } & \multicolumn{2}{|c|}{ A.B.D. } & \multicolumn{2}{|c|}{ İngiltere } & \multicolumn{2}{|c|}{ Malezya } \\
\hline & BIST100 & KAT30 & DJIND & DJISUS & FTSE100 & MSCIUKIS & KLCI & HIJRAH \\
\hline \multicolumn{9}{|c|}{ Ortalama Denklemi } \\
\hline Sabit & $0,0006^{* *}$ & $0,0008^{*}$ & $0,0004 *$ & $0,0005^{*}$ & 0,0002 & $-0,0001$ & 0,0001 & 0,0001 \\
\hline $\operatorname{AR}(1)$ & $0,5147^{*}$ & $-0,231 * * *$ & $-0,3937^{*}$ & $-0,7079$ & $0,9808 *$ & $-0,1431$ & $-0,3204$ & $-0,1341$ \\
\hline $\operatorname{AR}(2)$ & $0,4858^{*}$ & $-0,0985$ & 0,0079 & $-0,1507$ & $-0,0357$ & $-0,6349 *$ & $0,7489 *$ & $0,6472^{*}$ \\
\hline $\operatorname{AR}(3)$ & $-0,9725^{*}$ & $-0,0243$ & $0,3738^{*}$ & $0,6209 *$ & $0,0549 * * *$ & 0,5787 & 0,0191 & $-0,0592$ \\
\hline $\mathrm{AR}(4)$ & & $-0,3447 *$ & $0,7781 *$ & 0,9236 & $-0,0626^{* * *}$ & & $-0,0559$ & $-0,0703^{*}$ \\
\hline $\mathrm{AR}(5)$ & & $-0,8285^{*}$ & & 0,1112 & 0,0197 & & & 0,0039 \\
\hline $\mathrm{MA}(1)$ & $-0,5419 *$ & 0,2282 & $0,3631 *$ & 0,6629 & $-0,9738^{*}$ & 0,1884 & 0,3866 & 0,1912 \\
\hline $\mathrm{MA}(2)$ & $-0,4460^{*}$ & 0,1271 & 0,0105 & 0,1199 & & $0,6349 *$ & $-0,7032^{*}$ & $-0,6012 * *$ \\
\hline $\mathrm{MA}(3)$ & $0,9833^{*}$ & 0,0310 & $-0,3727 *$ & $-0,6523^{*}$ & & $0,6357^{* * * *}$ & $-0,0932$ & \\
\hline $\mathrm{MA}(4)$ & $-0,0356$ & $0,3578^{*}$ & $-0,7880 *$ & $-0,8995$ & & 0,0068 & & \\
\hline MA(5) & 0,0202 & $0,8264 *$ & & $-0,0904$ & & & & \\
\hline \multicolumn{9}{|c|}{ Varyans Denklemi } \\
\hline$\omega$ & $-0,3956^{*}$ & $-0,7565^{*}$ & $-0,8232^{*}$ & $-0,7775^{*}$ & $-0,6095^{*}$ & $-0,2010^{*}$ & $-0,4555^{*}$ & $-0,5028^{*}$ \\
\hline$\alpha_{1}$ & $0,0932 *$ & $0,1448^{*}$ & $0,2249 *$ & $0,1902^{*}$ & $0,1763^{*}$ & $0,0662^{*}$ & $0,1755^{*}$ & $0,1956^{*}$ \\
\hline$\beta_{1}$ & $0,9626 *$ & $0,9288^{*}$ & $0,9341 *$ & $0,9356 *$ & $0,9511 *$ & $0,9842^{*}$ & $0,9697 *$ & $0,9660^{*}$ \\
\hline$\gamma$ & $-0,0879 *$ & $-0,1188^{*}$ & $-0,2062 *$ & $-0,2433^{*}$ & $-0,1581 *$ & $-0,1198^{*}$ & $-0,0819 *$ & $-0,0765^{*}$ \\
\hline$\nu$ & $1,3344 *$ & $1,2896 *$ & $1,3357 *$ & $1,3661 *$ & $1,4941 *$ & $1,5993 *$ & $1,4046 *$ & $1,2733^{*}$ \\
\hline \multicolumn{9}{|c|}{ Varsayımsal Testler } \\
\hline $\mathrm{LM}(5)$ & $\begin{array}{l}1,8857 \\
{[0,094]}\end{array}$ & $\begin{array}{l}1,6514 \\
{[0,143]}\end{array}$ & $\begin{array}{l}0,7022 \\
{[0,622]}\end{array}$ & $\begin{array}{l}0,2485 \\
{[0,940]}\end{array}$ & $\begin{array}{l}0,9046 \\
{[0,477]}\end{array}$ & $\begin{array}{l}2,8684 \\
{[0,014]}\end{array}$ & $\begin{array}{l}1,8668 \\
{[0,097]}\end{array}$ & $\begin{array}{l}1,0380 \\
{[0,393]}\end{array}$ \\
\hline $\mathrm{Q}(42)$ & $\begin{array}{l}34,059 \\
{[0,465]}\end{array}$ & $\begin{array}{l}29,028 \\
{[0,618]}\end{array}$ & $\begin{array}{l}43,960 \\
{[0,118]}\end{array}$ & $\begin{array}{l}40,424 \\
{[0,146]}\end{array}$ & $\begin{array}{l}31,810 \\
{[0,668]}\end{array}$ & $\begin{array}{l}33,759 \\
{[0,528]}\end{array}$ & $\begin{array}{l}25,066 \\
{[0,893]}\end{array}$ & $\begin{array}{l}23,144 \\
{[0,938]}\end{array}$ \\
\hline $\mathrm{Q}_{\mathrm{s}}(42)$ & $\begin{array}{l}38,708 \\
{[0,616]}\end{array}$ & $\begin{array}{l}34,712 \\
{[0,780]}\end{array}$ & $\begin{array}{l}23,357 \\
{[0,991]}\end{array}$ & $\begin{array}{l}25,365 \\
{[0,980]}\end{array}$ & $\begin{array}{l}49,868 \\
{[0,189]}\end{array}$ & $\begin{array}{l}59,823 \\
{[0,036]}\end{array}$ & $\begin{array}{l}39,105 \\
{[0,599]}\end{array}$ & $\begin{array}{l}41,096 \\
{[0,511]}\end{array}$ \\
\hline \multicolumn{9}{|c|}{ Log-olasılık ve Bilgi Kriteri Değerleri } \\
\hline log-ol. & 5274,39 & 5633,20 & 6362,81 & 6229,47 & 6128,61 & 5956,25 & 6789,42 & 6751,29 \\
\hline AIC & $-5,8481$ & $-6,2517$ & $-7,0818$ & $-6,9347$ & $-6,7925$ & $-6,5926$ & $-7,7489$ & $-7,7097$ \\
\hline SIC & $-5,8054$ & $-6,2028$ & $-7,0389$ & $-6,8856$ & $-6,7558$ & $-6,5530$ & $-7,7083$ & $-7,6691$ \\
\hline HQ & $-5,8323$ & $-6,2337$ & $-7,0659$ & $-6,9166$ & $-6,7789$ & $-6,5780$ & $-7,7339$ & $-7,6947$ \\
\hline
\end{tabular}

Tablo 3’te yer alan EGARCH $(1,1)$ modeli tahmin sonuçlarına göre, kaldıraç etkisinin varllğını gösteren gamma $(\gamma)$ parametresi, tüm endeksler için negatif ve $\% 1$ önem düzeyinde istatistiksel olarak anlamlıdır. Bu sonuç, kötü şokların oynaklık üzerinde iyi şoklara nazaran daha çok etki ettiğini göstermektedir. Ayrıca yine tüm endeksler için ARCH parametresi alfa ve GARCH parametresi beta $\% 1$ önem düzeyinde anlamlıdır. GED parametresi $(v)$ tüm endeksler için \%1 önem düzeyinde anlamlı ve 2'den küçük bulunmuştur. $\mathrm{Bu}$ sonuç hata terimlerinin dağılımının kalın kuyruklu olduğunu göstermektedir. Varsayımsal testler incelendiğinde ise BIST100, MSCIUKIS ve KLCI endeksleri hariç tüm endekslerin oynaklık tahmin modellerinden elde edilen hata terimlerinde $\% 1$ önem düzeyinde $\mathrm{ARCH}$ etkisinin ortadan kalktığ1 görülmektedir. BIST100 ve KLCI endekslerinin oynaklık modellerinden hata terimlerinde $\% 5$ önem düzeyinde ARCH etkisi bulunmazken, MSCIUKIS endeksinin oynaklık modelinden elde edilen hata terimlerinde $\% 1$ önem düzeyinde $\mathrm{ARCH}$ etkisi varlığını sürdürmektedir. Tüm endekslerin oynaklık tahminlerinden elde edilen hata terimlerinin karelerinde \%1 önem düzeyinde otokorelasyon sorunu bulunmamaktadır. Hata terimlerinin karelerinde ise MSCIUKIS endeksi hariç otokorelasyon sorunu bulunmazken, söz konusu endeks için \%5 önem düzeyinde oynaklık modelinden elde edilen hata terimlerinde otokorelasyon sorunu vardir. 
Tablo 4. GJR-GARCH (1,1) Modeli ile Oynakllk Tabmini Sonuclarn

\begin{tabular}{|c|c|c|c|c|c|c|c|c|}
\hline & \multicolumn{2}{|c|}{ Türkiye } & \multicolumn{2}{|c|}{ A.B.D. } & \multicolumn{2}{|c|}{ İngiltere } & \multicolumn{2}{|c|}{ Malezya } \\
\hline & BIST100 & KAT30 & DJIND & DJISUS & FTSE100 & MSCIUKIS & KLCI & HIJRAH \\
\hline \multicolumn{9}{|c|}{ Ortalama Denklemi } \\
\hline Sabit & $0,0007 * *$ & $0,0008^{*}$ & $0,0006^{*}$ & $0,0004^{*}$ & $0,0002 * * *$ & 0,0000 & $0,0002 *$ & 0,0002 \\
\hline $\mathrm{AR}(1)$ & $0,5148^{*}$ & $-0,2484 * *$ & $-0,3717^{*}$ & 0,1070 & $0,9901^{*}$ & $-0,1452$ & $0,1465^{*}$ & $-0,1482$ \\
\hline $\operatorname{AR}(2)$ & $0,4863^{*}$ & $-0,0879$ & 0,0203 & $-0,7871 *$ & $-0,0420$ & $-0,6516^{*}$ & $-0,1180^{*}$ & $0,6271 * *$ \\
\hline $\operatorname{AR}(3)$ & $-0,9737^{*}$ & $-0,0390$ & $0,3781^{*}$ & 0,0361 & $0,0544 * * *$ & $-0,5715$ & $0,9598^{*}$ & $-0,0527$ \\
\hline $\operatorname{AR}(4)$ & & $-0,3334 *$ & $0,7945^{*}$ & $-0,6233^{*}$ & $-0,0574 * * *$ & & $-0,0716^{*}$ & $-0,0730^{*}$ \\
\hline $\operatorname{AR}(5)$ & & $-0,8490^{*}$ & & $-0,484 * * *$ & 0,0193 & & & 0,0020 \\
\hline $\mathrm{MA}(1)$ & $-0,5380^{*}$ & $0,2460 * * *$ & $0,3379 *$ & $-0,1515$ & $-0,9790^{*}$ & 0,1859 & $-0,786^{*}$ & 0,2036 \\
\hline $\mathrm{MA}(2)$ & $-0,4578^{*}$ & 0,1136 & $-0,123$ & $0,8045^{*}$ & & $0,6498^{*}$ & $0,1070^{*}$ & $-0,5790 * *$ \\
\hline $\mathrm{MA}(3)$ & $0,9866^{*}$ & 0,0471 & $-0,3871 *$ & $-0,0800$ & & 0,6231 & $-0,9730^{*}$ & \\
\hline $\mathrm{MA}(4)$ & $-0,0269$ & $0,3457 *$ & $-0,8103^{*}$ & $0,6644 *$ & & 0,0036 & & \\
\hline $\mathrm{MA}(5)$ & 0,0110 & $0,8479 *$ & & 0,4391 & & & & \\
\hline \multicolumn{9}{|c|}{ Varyans Denklemi } \\
\hline$\omega$ & $0,0000^{*}$ & $0,0000^{*}$ & $0,0000^{*}$ & $0,0000^{*}$ & $0,0000^{*}$ & $0,0000^{*}$ & $0,0000^{*}$ & $0,0000^{*}$ \\
\hline$\alpha_{1}$ & 0,0040 & $-0,0056$ & $-0,0095$ & $-0,0453^{*}$ & $-0,0228 * * *$ & $-0,0096$ & $0,0458^{* *}$ & $0,0545^{*}$ \\
\hline$\beta_{1}$ & $0,8954^{*}$ & $0,8450^{*}$ & $0,7993^{*}$ & $0,8149 *$ & $0,8595^{*}$ & $0,9003^{*}$ & $0,8659 *$ & $0,8556^{*}$ \\
\hline$\gamma$ & $0,1017^{*}$ & $0,1522^{*}$ & $0,3141 *$ & $0,3900 *$ & $0,2379 *$ & $0,1677 *$ & $0,0987^{*}$ & $0,1039 *$ \\
\hline$\nu$ & $1,3331 *$ & $1,2876^{*}$ & $1,3312^{*}$ & $1,3432^{*}$ & $1,5011 *$ & $1,5795^{*}$ & $1,3840^{*}$ & $1,2674^{*}$ \\
\hline \multicolumn{9}{|c|}{ Varsayımsal Testler } \\
\hline $\mathrm{LM}(5)$ & $\begin{array}{l}0,9176 \\
{[0,468]} \\
\end{array}$ & $\begin{array}{l}1,1894 \\
{[0,312]} \\
\end{array}$ & $\begin{array}{l}0,5288 \\
{[0,755]} \\
\end{array}$ & $\begin{array}{l}0,5929 \\
{[0,705]} \\
\end{array}$ & $\begin{array}{l}0,6611 \\
{[0,653]} \\
\end{array}$ & $\begin{array}{l}1,1823 \\
{[0,315]} \\
\end{array}$ & $\begin{array}{l}1,0699 \\
{[0,375]} \\
\end{array}$ & $\begin{array}{l}0,5876 \\
{[0,709]} \\
\end{array}$ \\
\hline $\mathrm{Q}(42)$ & $\begin{array}{l}36,083 \\
{[0,371]} \\
\end{array}$ & $\begin{array}{l}30,207 \\
{[0,558]}\end{array}$ & $\begin{array}{l}45,327 \\
{[0,093]} \\
\end{array}$ & $\begin{array}{l}43,272 \\
{[0,088]} \\
\end{array}$ & $\begin{array}{l}31,897 \\
{[0,664]}\end{array}$ & $\begin{array}{l}33,908 \\
{[0,521]} \\
\end{array}$ & $\begin{array}{l}29,988 \\
{[0,709]} \\
\end{array}$ & $\begin{array}{l}23,232 \\
{[0,936]} \\
\end{array}$ \\
\hline $\mathrm{Q}_{\mathrm{s}}(42)$ & $\begin{array}{l}30,718 \\
{[0,873]}\end{array}$ & $\begin{array}{l}28,881 \\
{[0,938]} \\
\end{array}$ & $\begin{array}{r}19,654 \\
{[0,999]} \\
\end{array}$ & $\begin{array}{l}23,746 \\
{[0,990]} \\
\end{array}$ & $\begin{array}{r}50,769 \\
{[0,166]}\end{array}$ & $\begin{array}{l}44,847 \\
{[0,353]} \\
\end{array}$ & $\begin{array}{l}47,241 \\
{[0,267]} \\
\end{array}$ & $\begin{array}{l}38,666 \\
{[0,618]}\end{array}$ \\
\hline \multicolumn{9}{|c|}{ Log-olasıllk ve Bilgi Kriteri Değerleri } \\
\hline log-ol. & 5273,60 & 5633,51 & 6362,31 & 6222,08 & 6131,20 & 5924,25 & 6793,31 & 6751,32 \\
\hline AIC & $-5,8472$ & $-6,2521$ & $-7,0812$ & $-6,9264$ & $-6,7953$ & $-6,5904$ & $-7,7533$ & $-7,7097$ \\
\hline SIC & $-5,8045$ & $-6,2032$ & $-7,0383$ & $-6,8774$ & $-6,7587$ & $-6,5508$ & $-7,7127$ & $-7,6691$ \\
\hline HQ & $-5,8315$ & $-6,2340$ & $-7,0654$ & $-6,9083$ & $-6,7818$ & $-6,5758$ & $-7,7383$ & $-7,6947$ \\
\hline
\end{tabular}

Tablo 4'teki GJR-GARCH $(1,1)$ modeli tahmin sonuçlarına göre, kaldıraç etkisinin varlığını gösteren gamma $(\gamma)$ parametresi, tüm endeksler için pozitif ve $\% 1$ önem düzeyinde istatistiksel olarak anlamlıdır. EGARCH modelin aksine GJR-GARCH modelde kaldıraç etkisinin varlığından söz edilebilmesi için bu parametrenin pozitif olması gerekmektedir. Dolayısıyla, tüm endeksler için kaldıraç etkisinin geçerli olduğunu ve kötü şokların iyi şoklara göre oynaklğ̆1 daha çok artırdığını göstermektedir. Modelin varsayımlarının sağlanabilmesi için parametrelerin pozitif ve istatistiksel olarak anlamlı olması gerekmektedir. Omega $(\omega)$ ve beta parametreleri için bu varsayım tüm endeksler için $\% 1$ önem düzeyinde sağlanırken, alfa parametresi yalnızca KLCI ve HIJRAH endekslerine ait tahminlerde pozitif ve istatistiksel olarak anlamlı bulunmuştur. Alfa parametresi KAT30, DJIND, DJIS, FTSE100 ve MSCIUKIS endeksleri için yapılan tahminlerde negatif hesaplanırken, BIST100 için pozitif hesaplanmış ancak istatistiksel olarak anlamlı bulunamamıştır. ARCH ve otokorelasyon testleri sonucunda BIST100, KAT30, FTSE100, MSCIUKIS, KLCI ve HIJRAH endekslerinin oynaklık tahmin modellerinden elde edilen hata terimlerinde $\% 1$ önem düzeyinde varsayımsal bir sorun saptanmamıştır. DJIND ve DJIS endekslerinin oynaklık tahmin modellerinden elde edilen hata terimlerinde $\% 1$ önem düzeyinde ARCH etkisinin ortadan kalktığ 1 ve hata terimlerinin karelerinde otokorelasyon sorunu olmadığı görülmekle birlikte hata terimlerinde $\% 5$ önem düzeyinde otokorelasyon sorunu yoktur.

\section{En Uygun Oynaklık Modellerinin Belirlenmesi}

Oynaklıklarının tahmininde kullanılan GARCH, EGARCH ve GJR-GARCH modelleri arasinda seçim yapılırken, öncelikle söz konusu modellerin varsayımlarını ve kısıtlarını sağlamayan tahminler, alternatifler arasından çıkarılmışıı. Daha sonra modellerden elde edilen hata terimleri ile ilgili yapılan varsayımsal testler sonucunda ARCH etkisinin devam ettiği ve hata terimlerinde ve hata terimlerinin 
karelerinde otokorelasyon sorunu bulunan tahminler aynı şekilde alternatifler arasında yer almamıştır. Tüm varsayımları sağlayan oynaklık tahminleri arasında seçim yapılırken, öncelikle kaldıraç etkisini modellemeye imkân veren EGARCH ve GJR-GARCH modellerde kaldıraç etkisinin varllğına ve log-olasıllk değerleri ile bilgi kriterlerine bakılmıştır.

GARCH model tahminlerinde tüm endeksler için model kısıtlarının sağlandığı ve hata terimleri ile ilgili varsayımsal testler açısından herhangi bir problem olmadı̆̆1 görülmektedir. Bu bağlamda tüm endeksler için GARCH model tahminleri, en uygun model seçimine katılabilmektedir. EGARCH oynaklık tahmini sonuçları incelendiğinde, tüm endeksler yapılan tahminlerde kaldıraç etkisinin var olduğu ve ilgili parametrenin istatistiksel olarak anlamlı olduğu görülmektedir. Modellerden elde edilen hata terimleri ile ilgili varsayımsal testlere bakıldığında ise MSCIUKIS endeksi dışındaki tüm endeksler için hata terimleriyle ilgili varsayımsal bir problem olmadığı, söz konusu endeks için yapılan model tahmininden elde edilen hata terimlerinde ise ARCH etkisinin ortadan kalkmadığ ve hata terimlerinin karelerinde otokorelasyon problemi olduğu görülmektedir. Dolayısıyla MSCIUKIS endeksi hariç diğer tüm endeksler için EGARCH model tahminleri seçime katılabilmektedir. GJR-GARCH model tahminlerinde, parametrelerin pozitif olma kısıdının yalnızca BIST100, KLCI ve HIJRAH endeksleri için sağlandığı görülmektedir. $\alpha_{1}$ parametresi diğer endeksler için negatif tahmin edilmiştir. $\alpha_{1}$ parametresi BIST100 endeksi için her ne kadar pozitif tahmin edilmisse de istatistiksel olarak anlamlı bulunamamıştır. Hata terimleri ile ilgili varsayımsal testler açısından ise endekslerin tamamı için varsayımsal bir problem tespit edilememiştir. Sayılan nedenlerden ötürü, GJR-GARCH tahminlerinden yalnızca KLCI ve HIJRAH endeksleri için yapılan tahminler, en uygun oynaklık modeli tahminine katılabilmektedir.

Tablo 5. İslami ve Konvansiyonel Hisse Senedi Endeksleri İcin En Uygun Oynakllk. Modeli Tabminleri

\begin{tabular}{|c|c|c|c|c|c|c|c|c|}
\hline & \multicolumn{2}{|c|}{ Türkiye } & \multicolumn{2}{|c|}{ A.B.D. } & \multicolumn{2}{|c|}{ İngiltere } & \multicolumn{2}{|c|}{ Malezya } \\
\hline & BIST100 & KAT30 & DJIND & DJISUS & FTSE100 & MSCIUKIS & KLCI & HIJRAH \\
\hline & EGARCH & EGARCH & EGARCH & EGARCH & EGARCH & GARCH & GJR-GARCH & GJR-GARCH \\
\hline \multicolumn{9}{|c|}{ Ortalama Denklemi } \\
\hline Sabit & $0,0006^{* *}$ & $0,0008^{*}$ & $0,0004 *$ & $0,0005^{*}$ & 0,0002 & $-0,0003^{* * *}$ & $0,0002 *$ & 0,0002 \\
\hline $\mathrm{AR}(1)$ & $0,5147 *$ & $-0,231 * * *$ & $-0,3937 *$ & $-0,7079$ & $0,9808^{*}$ & $-0,1290$ & $0,1465^{*}$ & $-0,1482$ \\
\hline $\mathrm{AR}(2)$ & $0,4858^{*}$ & $-0,0985$ & 0,0079 & $-0,1507$ & $-0,0357$ & $-0,6696^{*}$ & $-0,1180^{*}$ & 0,6271 ** \\
\hline $\operatorname{AR}(3)$ & $-0,9725^{*}$ & $-0,0243$ & $0,3738^{*}$ & $0,6209 *$ & $0,0549 * * *$ & $-0,5625$ & $0,9598^{*}$ & $-0,0527$ \\
\hline $\operatorname{AR}(4)$ & & $-0,3447^{*}$ & $0,7781 *$ & 0,9236 & $-0,0626^{* * *}$ & & $-0,0716^{*}$ & $-0,0730^{*}$ \\
\hline $\operatorname{AR}(5)$ & & $-0,8285^{*}$ & & 0,1112 & 0,0197 & & & 0,0020 \\
\hline $\mathrm{MA}(1)$ & $-0,5419 *$ & 0,2282 & $0,3631 *$ & 0,6629 & $-0,9738^{*}$ & 0,1673 & $-0,786^{*}$ & 0,2036 \\
\hline $\mathrm{MA}(2)$ & $-0,4460^{*}$ & 0,1271 & 0,0105 & 0,1199 & & $0,6608^{*}$ & $0,1070^{*}$ & $-0,5790 * *$ \\
\hline $\mathrm{MA}(3)$ & $0,9833^{*}$ & 0,0310 & $-0,3727 *$ & $-0,6523^{*}$ & & 0,6126 & $-0,9730^{*}$ & \\
\hline $\mathrm{MA}(4)$ & $-0,0356$ & $0,3578^{*}$ & $-0,7880^{*}$ & $-0,8995$ & & $-0,0018$ & & \\
\hline MA(5) & 0,0202 & $0,8264 *$ & & $-0,0904$ & & & & \\
\hline \multicolumn{9}{|c|}{ Varyans Denklemi } \\
\hline$\omega$ & $-0,3956^{*}$ & $-0,7565^{*}$ & $-0,8232 *$ & $-0,7775^{*}$ & $-0,6095^{*}$ & $0,0000^{*}$ & $0,0000^{*}$ & $0,0000^{*}$ \\
\hline$\alpha_{1}$ & $0,0932 *$ & $0,1448^{*}$ & $0,2249 *$ & $0,1902 *$ & $0,1763 *$ & $0,1079 *$ & $0,0458 * *$ & $0,0545^{*}$ \\
\hline$\beta_{1}$ & $0,9626^{*}$ & $0,9288^{*}$ & $0,9341 *$ & $0,9356^{*}$ & $0,9511 *$ & $0,8600^{*}$ & $0,8659 *$ & $0,8556^{*}$ \\
\hline$\gamma$ & $-0,0879 *$ & $-0,1188^{*}$ & $-0,2062^{*}$ & $-0,2433^{*}$ & $-0,1581^{*}$ & $1,4680^{*}$ & $0,0987 *$ & $0,1039 *$ \\
\hline$\nu$ & $1,3344 *$ & $1,2896^{*}$ & $1,3357^{*}$ & $1,3661 *$ & $1,4941 *$ & $0,0000^{*}$ & $1,3840^{*}$ & $1,2674^{*}$ \\
\hline \multicolumn{9}{|c|}{ Varsayımsal Testler } \\
\hline $\mathrm{LM}(5)$ & $\begin{array}{l}1,8857 \\
{[0,094]} \\
\end{array}$ & $\begin{array}{l}1,6514 \\
{[0,143]} \\
\end{array}$ & $\begin{array}{l}0.7022 \\
{[0,622]}\end{array}$ & $\begin{array}{l}0,2485 \\
{[0,940]} \\
\end{array}$ & $\begin{array}{l}0,9046 \\
{[0,477]} \\
\end{array}$ & $\begin{array}{l}0,7518 \\
{[0,585]}\end{array}$ & $\begin{array}{l}1,0699 \\
{[0,375]} \\
\end{array}$ & $\begin{array}{l}0,5876 \\
{[0,709]}\end{array}$ \\
\hline $\mathrm{Q}(42)$ & $\begin{array}{l}34.059 \\
{[0,465]}\end{array}$ & $\begin{array}{l}29,028 \\
{[0,618]}\end{array}$ & $\begin{array}{l}43,960 \\
{[0,118]}\end{array}$ & $\begin{array}{l}40,424 \\
{[0,146]}\end{array}$ & $\begin{array}{l}31,810 \\
{[0,668]}\end{array}$ & $\begin{array}{l}37,302 \\
{[0,364]}\end{array}$ & $\begin{array}{l}29,988 \\
{[0,709]}\end{array}$ & $\begin{array}{l}23,232 \\
{[0,936]}\end{array}$ \\
\hline $\mathrm{Q}_{\mathrm{s}}(42)$ & $\begin{array}{l}38.708 \\
{[0,616]}\end{array}$ & $\begin{array}{l}34,712 \\
{[0,780]}\end{array}$ & $\begin{array}{l}23,357 \\
{[0,991]}\end{array}$ & $\begin{array}{l}25,365 \\
{[0,980]}\end{array}$ & $\begin{array}{l}49,868 \\
{[0,189]}\end{array}$ & $\begin{array}{l}36,410 \\
{[0,714]}\end{array}$ & $\begin{array}{l}47,241 \\
{[0,267]}\end{array}$ & $\begin{array}{l}38,666 \\
{[0,618]}\end{array}$ \\
\hline
\end{tabular}


Tablo 5'te, en uygun oynaklık tahmin modelleri yer almaktadır. Seçim yapilırken daha önce de belirtildiği gibi, model kısıtları ve hata terimleri ile ilgili varsayımsal bir sorun olmadığı taktirde öncelik, kaldıraç etkisinin modellenmesine imkân tanıyan EGARCH ve GJR-GARCH modellere verilmiştir. Bu bağlamda yalnızca MSCIUKIS endeksinin oynaklık tahminlerinde EGARCH model için hata terimleriyle ilgili varsayımsal sorunlar ve GJR-GARCH model için modelin kısıtları ile ilgili sorunlar bulunduğundan, söz konusu endeks için GARCH model tahmini sonuçlarına tabloda yer verilmiştir. KLCI ve HIJRAH endeksleri dışındaki endekslerin GJR-GARCH tahminlerinde, modelin kısıtlarının sağlanamaması nedeniyle, BIST100, KAT30, DJIND, DJISUS ve FTSE100 endeksleri için EGARCH model sonuçları en uygun model tahminleri olarak belirlenmiştir. KLCI ve HIJRAH endeksleri için ise EGARCH ve GJRGARCH endeksleri arasından seçim, Tablo 3 ve Tablo 4'te yer alan log-olasillk değerlerine ve AIC, SIC, HQ bilgi kriterlerine göre karar verilmiştir. Bu nedenle KLCI ve HIJRAH endeksleri için GJR-GARCH model tahminleri tabloya alınmıştır.

\section{Hisse Senedi Endekslerinin Oynaklıklarının Karşılaştırılması}

Hisse Senedi endekslerinin oynakliklanı, GARCH $(1,1)$ modeli tahmin sonuçlarına göre oynaklik kalıcılığı, oynaklık yarılanma süresi, uzun dönem oynaklık ve günlük oynaklık kıstaslarına göre karşılaştırılmıştır. Kıyaslamaların GARCH model sonuçlarına göre yapılmasının nedeni, kıyaslamada kullanılan kıstasların bu model üzerinden tahmin edilen parametre sonuçlarına göre yapılabiliyor olmasıdır. Ayrıca karşılaştırma yaparken aynı model sonuçlarını kullanmak daha tutarlı yorum yapılmasını sağlamaktadır.

Tablo 6. Tüm Endekslere Ait GARCH $(1,1)$ Modeli Oynakllk Tahminleri

\begin{tabular}{|c|c|c|c|c|c|c|c|c|}
\hline Endeks & BIST100 & KAT30 & DJIND & DJISUS & FTSE100 & MSCIUKIS & KLCI & HIJRAH \\
\hline Model & GARCH & GARCH & GARCH & GARCH & GARCH & GARCH & GARCH & GARCH \\
\hline \multicolumn{9}{|c|}{ Ortalama Denklemi } \\
\hline Sabit & $0,0008^{*}$ & $0,0009 *$ & $0,0007^{*}$ & $0,0007^{*}$ & $0,0004 *$ & $-0,0003^{* * *}$ & $0,0002^{*}$ & $0,0002^{* *}$ \\
\hline $\operatorname{AR}(1)$ & $-0,2423$ & $-0,1627$ & $-0,2574$ & $-0,1563$ & $0,9631 *$ & $-0,1290$ & $0,1172 *$ & $-0,1341$ \\
\hline $\operatorname{AR}(2)$ & 0,1362 & $-0,1434$ & 0,1046 & 0,0215 & $-0,0369$ & $-0,6696^{*}$ & $-0,1353^{*}$ & $0,6517^{*}$ \\
\hline $\operatorname{AR}(3)$ & $-0,586 * * *$ & 0,0301 & $0,5308^{* *}$ & $0,3988^{*}$ & 0,0480 & $-0,5625$ & $0,9409 *$ & $-0,0529$ \\
\hline $\operatorname{AR}(4)$ & & $-0,3815^{*}$ & 0,4418 & 0,6884 & $-0,065^{* * *}$ & & $-0,0633^{*}$ & $-0,0673^{*}$ \\
\hline $\mathrm{AR}(5)$ & & $-0,7703^{*}$ & & $-0,1676$ & 0,0276 & & & 0,0051 \\
\hline $\mathrm{MA}(1)$ & 0,2153 & 0,1614 & 0,2032 & 0,1023 & $-0,9684 *$ & 0,1673 & $-0,058 * * *$ & 0,1849 \\
\hline $\mathrm{MA}(2)$ & $-0,1229$ & 0,1749 & $-0,1153$ & $-0,0377$ & & $0,6608^{*}$ & $0,1246^{*}$ & $-0,6131 * *$ \\
\hline $\mathrm{MA}(3)$ & $0,6028^{*}$ & $-0,0234$ & $-0,5215^{* *}$ & $-0,4347^{*}$ & & 0,6126 & $-0,9540^{*}$ & \\
\hline $\mathrm{MA}(4)$ & $-0,0007$ & $0,3953 *$ & $-0,4438$ & $-0,6950$ & & $-0,0018$ & & \\
\hline $\mathrm{MA}(5)$ & 0,0199 & $0,7642^{*}$ & & 0,1704 & & & & \\
\hline \multicolumn{9}{|c|}{ Varyans Denklemi } \\
\hline$\omega$ & $0,0000^{*}$ & $0,0000^{*}$ & $0,0000^{*}$ & $0,0000^{*}$ & $0,0000^{*}$ & $0,0000^{*}$ & $0,0000^{*}$ & $0,0000^{*}$ \\
\hline$\alpha_{1}$ & $0,0563^{*}$ & $0,1008^{*}$ & $0,1911 *$ & $0,1725^{*}$ & $0,1329 *$ & 0,1079* & $0,1080^{*}$ & $0,1056^{*}$ \\
\hline$\beta_{1}$ & $0,9154^{*}$ & $0,8317^{*}$ & $0,7731^{*}$ & $0,7973^{*}$ & $0,8348^{*}$ & $0,8600^{*}$ & $0,8598^{*}$ & $0,8564 *$ \\
\hline$\nu$ & $1,3207 *$ & $1,2528^{*}$ & $1,2703^{*}$ & $1,2616^{*}$ & $1,3887 *$ & $1,4680^{*}$ & $1,3636^{*}$ & $1,2470^{*}$ \\
\hline \multicolumn{9}{|c|}{ Karşılaştırma Ölçütleri } \\
\hline$\alpha_{i}+\beta_{i}$ & 0,9717 & 0,9325 & 0,9642 & 0,9697 & 0,9677 & 0,9679 & 0,9678 & 0,9621 \\
\hline Yarılanma Süresi & 24,15 & 9,92 & 19,01 & 22,57 & 21,10 & 21,26 & 21,17 & 17,94 \\
\hline $\begin{array}{c}\text { Uzun Dönem } \\
\text { Oynaklık }\end{array}$ & 0,000195 & 0,000134 & 0,000089 & 0,000104 & 0,000092 & 0,000102 & 0,000033 & 0,000034 \\
\hline Günlük Oynaklık & 0,013967 & 0,011574 & 0,009438 & 0,010221 & 0,009588 & 0,010113 & 0,005710 & 0,005811 \\
\hline
\end{tabular}

Not: *,** ve *** işaretleri sırasıyla $\% 1, \% 5$ ve $\% 10$ önem düzeylerinde ilgili değişkenin anlamlı olduğunu, $\alpha_{i}+\beta_{i}$ toplamı oynaklık kalıcllı̆ı̆ı göstermektedir.

ARCH parametresi $\alpha_{1}$ katsayısı cari dönem oynaklığı üzerindeki geçmiş dönem şoklarının etkisini gösterirken, GARCH parametresini ifade eden $\beta_{1}$ katsayısı önceki dönem koşullu varyansının cari dönem oynaklığ üzerindeki etkisini göstermektedir (Kayalıdere, 2013, s. 47; Rana ve Akhter, 2015, s. 12). Tablo 6'da yer alan sonuçlara göre BIST100 endeksinin cari dönem oynaklı̆̆ üzerinde değişkenliğin \%5,63'lük 
kısmı geçmiş dönem oynaklık şoklarından kaynaklanırken, \%91,54’ük kısmı önceki dönem koşullu varyansından kaynaklanmaktadır. KAT30 endeksinin ise cari dönem oynaklığı üzerinde değişkenliğin \%10,08’lik kısmının geçmiş dönem oynaklık şoklarından, \%83,17’lik kısmının önceki dönem koşullu varyansından kaynaklandığı söylenebilir. Her iki endeks için de $\alpha_{1}$ katsayısının $\beta_{1}$ katsayısından düşük olması, endekslerin oynaklıklarının kendi geçmiş değerlerine daha duyarlı olduğunu göstermektedir. Ancak konvansiyonel endeksin oynaklığı geçmiş dönem oynaklığına daha duyarllyken, İslami endeksin oynaklığının şoklara daha duyarlı olduğu ifade edilebilir. Konvansiyonel endeksin $\beta_{1}$ katsayısının İslami endeksin $\beta_{1}$ katsayısından daha yüksek olması, konvansiyonel endeksin getirileri üzerinde dalgalanmaların daha kalıcı olduğunun bir göstergesidir. $\alpha_{1}$ ve $\beta_{1}$ katsayılarının toplamı $\left(\alpha_{\mathrm{i}}+\beta_{\mathrm{i}}\right)$ oynaklık kalıcıllğının ölçüsüdür. $\alpha_{i}+\beta_{i}$ toplamı konvansiyonel endeksin oynaklık tahmini için 0,9717 iken, İslami endeksin oynaklığı için 0,9325 'dir. Yani konvansiyonel endeksin oynaklığı daha kalıcıdır ve oynaklık daha uzun bir sürede sönümlenmektedir. Oynaklık yarılanma süreleri de bu yorumu desteklemektedir. BIST100 endeksinin oynaklık değişimi 24,15 günde, KAT30 endeksinin ki ise sadece 9,92 günde eski seviyesine dönmektedir. Uzun dönem oynaklıklara bakıldığında, konvansiyonel endeks için uzun dönem oynaklı̆̆ın 0,000195, İslami endeks için ise 0,000134 olarak hesaplandığ1 görülmektedir. Uzun dönem oynaklık üzerinden hesaplanan günlük oynaklık değerlerine göz atıldığında ise yine benzer bir sonuçla karşılaşılmaktadır. Günlük oynaklık BIST100 endeksi için \%1,39 olarak, KAT30 endeksi için \%1,15 olarak hesaplanmıştır. Günlük oynaklık açısından da İslami endeksin oynaklı̆̆ı, konvansiyonel endeksin oynaklığından düşüktür. Risk ve belirsizlik bağlamında değerlendirildiğinde, Türkiye İslami hisse senedi piyasasının, konvansiyonel hisse senedi piyasasına nazaran daha düşük bir risk seviyesine sahip olduğu ifade edilebilir.

A.B.D. konvansiyonel hisse senedi endeksinin cari dönem oynakllğı üzerinde değişkenliğin \%19,11’lik kısmının geçmiş dönem oynaklık şoklarından kaynaklandığ1, \%77,31'lik kısmının ise önceki dönem koşullu varyansından kaynaklandığ1 görülmektedir. İslami hisse senedi endeksinin ise cari dönem oynaklğg üzerindeki değişkenliğin \%17,25'lik kısmının geçmiş dönem oynaklık şoklanından, $\% 79,73$ ’lük kısmının ise önceki dönem koşullu varyansından kaynaklandığı söylenebilir. Her iki endeks için de $\alpha_{1}$ katsayısının $\beta_{1}$ katsayısından düşük olması, endekslerin oynaklıklarının kendi geçmiş değerlerine daha duyarlı olduğunu göstermektedir. Ancak İslami endeksin oynaklığı geçmiş dönem oynaklığına daha duyarlıyken, konvansiyonel endeksin oynaklığının şoklara daha duyarlı olduğu ifade edilebilir. İslami endeksin $\beta_{1}$ katsayısının konvansiyonel endeksin $\beta_{1}$ katsayısından daha yüksek olması, konvansiyonel endeksin getirileri üzerinde dalgalanmaların daha kalıcı olduğunun bir göstergesidir. Ancak aradaki fark çok büyük değildir. $\alpha_{\mathrm{i}}+\beta_{\mathrm{i}}$ toplamı konvansiyonel endeksin oynaklık tahmini için 0,9642 iken, İslami endeksin oynaklığı için 0,9697'dir. Yani İslami endeksin oynaklığı daha kalıcıdır ancak aradaki fark çok düşüktür. Bu nedenle oynaklık kalıcılığı açısından iki endeks arasından önemli bir farklılık olduğunu söylemek mümkün değildir. Oynaklık yarılanma süreleri, DJIND endeksi için 19,01 gün iken DJISUS endeksi için 22,57 gündür. Bu sonuca göre İslami endeksin oynaklık değişimleri daha uzun sürede sönümlenmektedir. Uzun dönem oynaklıklar ise konvansiyonel endeks için 0,000089, İslami endeks için ise 0,000104 olarak hesaplanmıştır. Yani İslami endeksin oynaklığı konvansiyonel endekse göre daha yüksektir. Günlük oynaklıklara bakıldığında ise DJIND endeksi için \%0,94 olarak, DJISUS endeksi için \%1,02 olarak hesaplandığ1 görülmektedir. Günlük oynaklık açısından da İslami endeksin oynaklı̆̆ı, konvansiyonel endeksin oynaklığından daha yüksektir. Risk ve belirsizlik bağlamında değerlendirildiğinde, A.B.D. İslami hisse senedi piyasasının, Türkiye'nin aksine konvansiyonel hisse senedi piyasasına nispetle daha yüksek bir risk seviyesine sahip olduğu söylenebilir.

FTSE100 endeksinin cari dönem oynaklığı üzerindeki değişkenliğin \%13,29’luk kısmı geçmiş dönem oynaklık şoklarından kaynaklanırken, \%83,48’lik kısmı önceki dönem koşullu varyansından kaynaklanmaktadır. MSCIUKIS endeksinin ise cari dönem oynaklı̆ı üzerinde değişkenliğin \%10,79’luk kısmının geçmiş dönem oynaklık şoklarından, \%86’lık kısmının önceki dönem koşullu varyansından kaynaklandığı söylenebilir. Her iki endeks için de $\alpha_{1}$ katsayısının $\beta_{1}$ katsayısından düşük olması, endekslerin oynaklıklarının kendi geçmiş değerlerine daha duyarlı olduğunu göstermektedir. Ancak İslami endeksin oynaklığı geçmiş dönem oynaklığına daha duyarlıyken, konvansiyonel endeksin oynaklığının şoklara daha duyarlı olduğu ifade edilebilir. İslami endeksin $\beta_{1}$ katsayısının konvansiyonel endeksin $\beta_{1}$ katsayısından daha yüksek olması, İslami endeksin getirileri üzerinde dalgalanmaların daha kalıcı olduğunun bir göstergesidir. $\alpha_{i}+\beta_{i}$ toplamı konvansiyonel endeksin oynaklık tahmini için 0,9677 iken, İslami endeksin 
oynaklığı için 0,9679'dur. Yani İslami endeksin oynaklığı daha kalıcıdır ancak aradaki fark A.B.D. İslami ve konvansiyonel hisse senedi endekslerinde olduğu gibi çok düşüktür. Bu nedenle oynaklık kalıcilğg açısından iki endeks arasında önemli bir farklılık olduğunu söylemek mümkün değildir. Oynaklık yarılanma süreleri, FTSE100 endeksi için 21,10 gün iken MSCIUKIS endeksi için 21,26 gündür. Oynaklık yarllanma süreleri arasındaki fark da oynaklık kalıcılığında olduğu gibi çok düşüktür. Her iki endeksin oynaklık değişimleri yaklaşık 21 günde eski düzeyine dönmektedir. Uzun dönem oynaklıklara bakıldığında, konvansiyonel endeks için uzun dönem oynaklığın 0,000092, İslami endeks için ise 0,000102 olarak hesaplandığ1 görülmektedir. Uzun dönem oynaklık üzerinden hesaplanan günlük oynaklık değerlerine göz atıldığında ise yine benzer bir sonuçla karşılaşılmaktadır. Günlük oynaklık FTSE100 endeksi için \%0,95 olarak, MSCIUKIS endeksi için \%1,02 olarak hesaplanmışır. Günlük oynaklık açısından da konvansiyonel endeksin oynaklığı, İslami endeksin oynaklığından düşüktür. Sonuç olarak, İngiltere İslami hisse senedi piyasasının riski düzeyi, A.B.D.'deki sonuçlarla paralel olarak konvansiyonel hisse senedi piyasasından daha yüksektir. Ancak risk düzeyleri arasındaki farklılık, A.B.D. İslami ve konvansiyonel hisse senedi endeksleri arasındaki farka kıyasla çok daha düşüktür.

Malezya konvansiyonel hisse senedi endeksinin cari dönem oynaklığı üzerindeki değişkenliğin \%19,8’lik kısmının geçmiş dönem oynaklık şoklarından kaynaklandığı, \%85,98’lik kısmının ise önceki dönem koşullu varyansından kaynaklandığı görülmektedir. İslami hisse senedi endeksinin ise cari dönem oynaklığ1 üzerinde değişkenliğin \%10,56'lik kısmının geçmiş dönem oynaklık şoklarından, \%85,64'lük kısmının ise önceki dönem koşullu varyansından kaynaklandığ söylenebilir. Her iki endeks için de $\alpha_{1}$ katsayısının $\beta_{1}$ katsayısından düşük olması, endekslerin oynaklıklarının kendi geçmiş değerlerine daha duyarlı olduğunu göstermektedir. Ancak konvansiyonel endeksin oynaklığı geçmiş dönem oynaklığına daha duyarllyken, İslami endeksin oynaklı̆̆ının şoklara daha duyarlı olduğu ifade edilebilir. İslami endeksin $\beta_{1}$ katsayısının konvansiyonel endeksin $\beta_{1}$ katsayısından daha yüksek olması, İslami endeksin getirileri üzerinde dalgalanmaların daha kalıcı olduğunun bir göstergesidir. Ancak aradaki fark çok büyük değildir. $\alpha_{i}+\beta_{i}$ toplamı konvansiyonel endeksin oynaklık tahmini için 0,9678 iken, İslami endeksin oynaklığı için 0,9621'dir. Yani konvansiyonel endeksin oynaklı̆ı daha kalıcıdır ancak aradaki fark çok düşüktür. Bu nedenle oynaklık kalıcılığı açısından iki endeks arasından önemli bir farklılık olduğunu söylemek mümkün değildir. Oynaklık yarılanma süreleri, KLCI endeksi için 21,17 gün iken HIJRAH endeksi için 17,94 gündür. Dolayısıyla İslami endeks, ortalamasına daha hızlı dönmektedir. Uzun dönem oynaklıklar ise konvansiyonel endeks için 0,000033, İslami endeks için ise 0,000034 olarak hesaplanmıştır. Yani İslami endeksin oynaklığı konvansiyonel endekse göre daha yüksektir, ancak aradaki farkın çok düşük olduğu görülmektedir. Benzer durum günlük oynaklıklar için de geçerlidir. Günlük oynaklıklar, KLCI endeksi için $\% 0,57$, HIJRAH endeksi için \%0,58 olarak hesaplanmıştır. Günlük oynaklık açısından da İslami endeksin oynaklığı, konvansiyonel endeksin oynaklığından daha yüksek olsa da aradaki fark çok düşüktür. Risk ve belirsizlik bağlamında değerlendirildiğinde, Malezya İslami hisse senedi piyasasının, konvansiyonel hisse senedi piyasasına nispetle daha yüksek bir risk seviyesine sahip olduğu söylenebilir. Ancak hem Malezya İslami hisse senedi piyasasının oynaklık yarılanma süresinin konvansiyonel hisse senedi piyasasından daha düşük olması hem de hesaplanan gerek uzun dönemli gerekse günlük oynaklıkların arasındaki farkların çok düşük olması, çok net bir yargıda bulunmayı engellemektedir.

Tablo 6'da yer alan sonuçlar, İslami hisse senedi endekslerinin kendi aralarındaki oynaklıklarını karşılaştırmak açısından incelendiğinde, cari dönem oynaklıkları üzerindeki değişkenliğin; KAT30 endeksinin \%10,08'lik kısm1, DJISUS endeksinin \%17,25'lik kısm1, MSCIUKIS endeksinin \%10,79 kısmı ve HIJRAH endeksinin \%10,56'lk kısmı geçmiş dönem oynaklık şoklarından kaynaklanmaktadır. Oynaklık değişkenliklerinin önceki dönem koşullu varyansından kaynaklanan kısımları ise KAT30 için \%83,17, DJISUS için \%79,73, MSCIUKIS için \%86 ve HIJRAH endeksi için \%85,64’tür. Tüm endeksler için $\alpha_{1}$ katsayısının $\beta_{1}$ katsayısından düşük olması, endekslerin oynaklıklarının kendi geçmiş değerlerine daha duyarlı olduğunu göstermektedir. $\alpha_{i}+\beta_{i}$ toplamları KAT30 için 0,9325, DJISUS için 0,9697, MSCIUKIS için 0,9679 ve HIJRAH endeksi için 0,9621 'dir. Dolayısıyla oynaklık kalıcilığının en yüksek olduğu İslami Hisse senedi endeksi A.B.D. İslami hisse senedi endeksi iken en düşük olduğu endeks Türkiye İslami hisse senedi endeksidir. Ancak A.B.D., İngiltere ve Malezya İslami hisse senedi endekslerinin oynaklik kalıc1ıkları arasındaki farklar oldukça düşüktür. Oynaklık yarılanma süreleri de bu yorumu desteklemektedir. Oynaklık yarılanma süreleri KAT30 için 9,92 gün, DJISUS için 22,57 gün, MSCIUKIS için 21,26 gün ve HIJRAH endeksi için 17,94 gün olarak hesaplanmıştır. Türkiye İslami hisse senedi endeksinde yaşanan oynaklık değişimleri en kısa sürede eski seviyesine dönerken, A.B.D. İslami hisse senedi endeksinde yaşanan oynaklık değişimlerinin eski seviyesine dönmesi İslami hisse senedi endeksleri 
arasında en uzun süre alandır. Uzun dönem oynaklıklara bakıldığında, KAT30 endeksi için uzun dönem oynaklığın 0,000134, DJISUS endeksi için 0,000104, MSCIUKIS endeksi için 0,000102 ve HIJRAH endeksi için 0,000034 olarak hesaplandığ1 görülmektedir. Bu sonuçlara göre en düşük oynaklık Malezya hisse senedi endeksine ait iken, en yüksek oynaklık Türkiye İslami hisse senedi endeksine aittir. Oynaklikların küçükten büyüğe doğru sıralamasında sırasıyla ikinci ve üçüncü sırada yer alan İngiltere ve A.B.D. İslami hisse senedi endekslerinin uzun dönemli oynaklıkları arasındaki fark ise çok düşüktür. Uzun dönem oynaklık üzerinden hesaplanan günlük oynaklık değerlerine göz atıldığında ise yine benzer sonuçlarla karşılaşılmaktadır. Günlük oynaklık KAT30 endeksi için \%1,15, DJISUS endeksi için \%1,02, MSCIUKIS endeksi için \%1,01 ve HIJRAH endeksi için \%0,58 olarak hesaplanmıştır. Günlük oynaklık açısından da en düşük oynaklık Malezya İslami hisse senedi endeksine ait iken en yüksek oynaklık Türkiye İslami hisse senedi endeksine aittir. Yine İngiltere ve A.B.D. İslami hisse senedi endekslerinin günlük oynaklıkları birbirine çok yakındır. Risk ve belirsizlik bağlamında değerlendirildiğinde, en düşük risk seviyesine sahip İslami hisse senedi piyasasının Malezya İslami hisse senedi piyasası olduğu, ardından sırasıyla İngiltere, A.B.D İslami hisse senedi piyasalarının geldiği ve en riskli İslami hisse senedi piyasasının Türkiye İslami hisse senedi piyasasının olduğu görülmektedir. Bununla birlikte İngiltere ve A.B.D. İslami hisse senedi piyasalarının oynaklıkları arasındaki farkın çok düşük olduğunu belirtmek gerekmektedir. Oynaklığın en kısa sürede sönümlediği İslami hisse sendi piyasası Türkiye İslami hisse senedi piyasasıdır. Yine oynaklık kalıcılığının en düşük olduğu piyasa, Türkiye İslami hisse senedi piyasasıdır.

\section{Tartışma, Sonuç ve Öneriler}

Finansal anlamda beklenen getirinin gerçekleşen getiriden sapma olasıllğ̆1 olan riskin ölçümünde kullanılan ölçütlerden birisi de oynaklıktır. Bu hususta, İslami hisse senedi piyasalarının yapılan filtreleme nedeniyle konvansiyonel hisse senedi piyasalarından daha az sayıda hisse senedi içermesi ve bu hisse senetlerinin özellikle faaliyet alanı filtrelemesi nedeniyle sınırlı sayıdaki sektörde faaliyet gösteren şirketlere ait olması nedeniyle daha riskli oldukları yönünde bir görüş mevcuttur. Bu görüşün karşısında olanlar ise filtrelemenin bu görüşün tam aksi yönünde etki göstereceğini, zira İslami hisse senedi piyasalarının finansal filtreleme ölçütleri nedeniyle daha düşük kaldıraç oranlarına sahip şirketlerden oluştuğunu, bu durumun da İslami hisse senedi piyasalarının riskini azaltacağını ileri sürmektedir.

$\mathrm{Bu}$ çalışmada, İslami ve konvansiyonel hisse senedi endekslerinin oynaklıkları incelenmiş ve karşılaştırılmıştır. Oynaklık tahmin sonuçlarına bakıldığında, en uygun oynaklık modelleri İngiltere İslami hisse senedi piyasası için GARCH $(1,1)$, Malezya konvansiyonel ve İslami hisse senedi piyasaları için GJRGARCH $(1,1)$, diğer tüm hisse senedi piyasaları için ise EGARCH $(1,1)$ modeli olarak belirlenmiştir. Kaldıraç etkisinin varlı̆̆nın tespit edilmesine olanak tanıyan EGARCH ve GJR-GARCH modellerin en iyi tahmin modeli olarak belirlendiği piyasaların tümü için kaldıraç etkisinin varlığı saptanmıştır. Bu sonuç, Abbes'in (2012) çalışması ile paralellik göstermektedir. Kaldıraç etkisinin varlı̆̆1, kötü şokların piyasaların oynakllğını iyi şoklara göre daha çok etkilediği göstermektedir. Diğer bir ifadeyle, fiyatlarda aşağı yönlü dalgalanmaların olduğu dönemlerde, piyasaların oynaklığı daha çok artmaktadır. Ülke bazında oynaklık karşılaştırması sonuçları ise şu şekilde özetlenebilir;

Türkiye İslami hisse senedi piyasasının oynaklığı, oynaklık kalıcıllğı, oynaklık yarılanma süresi, uzun dönemli ve günlük oynaklık ölçütlerinin dördüne göre de konvansiyonel hisse senedi piyasasına göre daha düşüktür. Bu sonuç, piyasalara ait standart sapma değerleri ile de örtüşmekte ve Seçme, Aksoy ve Uysal'ın (2016) çalışmaları ile benzerlik arz etmektedir. A.B.D. ve İngiltere İslami hisse senedi piyasalarının oynaklığı, kullanılan dört karşılaştırma ölçütüne göre de konvansiyonel hisse senedi piyasalarının oynaklıklarından daha yüksektir. Ancak şunu da belirtmekte fayda var ki, İngiltere İslami hisse senedi piyasasının oynaklığı ve oynaklık kalıcılığı, konvansiyonel hisse senedi endeksinin değerlerine çok yakındır. Bu sonuçlar, tıpkı Türkiye için yapılan analizlerde olduğu gibi, standart sapma değerleri ile uyumludur. Malezya hisse senedi piyasalarının oynaklık tahmin sonuçlarına göre ise İslami hisse senedi piyasasının oynaklık kalıcilığı ve oynaklık yarılanma süresi, konvansiyonel piyasadan daha düşüktür. Ancak İslami hisse senedi piyasasının uzun dönemli oynaklı̆g ve günlük oynaklı̆̆, az da olsa konvansiyonel piyasadan yüksektir. Bu sonuç, Romli, Mohamad ve Yusof un (2012) çalışmalarıyla örtüşmektedir. Bununla birlikte, aradaki farklılık çok düşüktür.

Çalışma kapsamında incelenen Türkiye, A.B.D., İngiltere ve Malezya İslami hisse senedi piyasalarının oynaklıkları karşılaştırıldığında, Türkiye İslami hisse senedi piyasasının oynaklık kalıcılığı ve oynaklık yarılanma süresi en düşük piyasa olduğu görülmektedir. Türkiye’nin ardından sırasıyla; Malezya, İngiltere ve A.B.D. İslami hisse senedi piyasaları gelmektedir. Ancak, özellikle oynaklık kalıcılıklarının, bu üç ülke 
için de birbirine çok yakın olduğunu belirtmekte fayda vardır. Uzun dönemli ve günlük oynaklıklara bakıldığında ise oynaklı̆̆ın en düşük olduğu İslami hisse senedi piyasasının Malezya'ya ait olduğu görülmektedir. Malezya'nın ardından sırasıyla İngiltere ve A.B.D. gelirken, Türkiye İslami hisse senedi piyasası oynaklığın en yüksek olduğu piyasadır. Bu sonuçlar, piyasalara ait standart sapma değerleri ile de hemen hemen örtüşmektedir. Risk ölçütü olarak standart sapma alındığında, yine riskin en düşük olduğu İslami hisse senedi piyasası Malezya, en yüksek olduğu ise Türkiye İslami hisse senedi piyasasıdır. Oynaklık tahmini sonuçları ile kıyaslandığında yalnızca A.B.D. ve İngiltere İslami hisse senedi piyasalarının yerleri değişmektedir.

Sonuçlar, İslami hisse senedi yatırımlarının İslami hisse senedi piyasalarında payları işlem gören şirketlerin düşük kaldıraç oranları nedeniyle daha az risk içerdiği görüşünün, gelişmekte olan ülke piyasalarında geçerli olduğunu, ancak gelişmiş ülke piyasalarında geçerli olmadığını göstermektedir. Bu durumun muhtemel sebebi, gelişmiş ülke İslami hisse senedi piyasalarında, filtreleme sonucunda konvansiyonel hisse senedi piyasalarına göre sınırlı sayıda sektörde faaliyet gösteren şirketlerin yer alıyor olması olarak açıklanabilir. Bu sonuçlar ışığında riski sevmeyen yatırımcılar, Türkiye ve Malezya İslami hisse senedi piyasalarına, konvansiyonel hisse piyasalarına nazaran düşük risk içermeleri nedeniyle yatırımda bulunabilirler. Uluslararası çeşitlendirme yapmayı düşünen yatırımcılar açısından ise riski en düşük İslami hisse senedi piyasası Malezya’ya aittir.

\section{Etik Beyan}

“İslami ve Konvansiyonel Hisse Senedi Endekslerinin Oynaklıkları Üzerine Bir İnceleme” başliklı çalısmanın yazım sürecinde bilimsel, etik ve alıntı kurallarına uyulmuş; toplanan veriler üzerinde herhangi bir tahrifat yapılmamış ve bu çalışma herhangi başka bir akademik yayın ortamına değerlendirme için gönderilmemiştir.

\section{Kaynakça}

Abbes, M. B. (2012). Risk and return of islamic and conventional indices. International Journal of Euro-Mediterranean Studies, 5(1), 1-23.

Alhabshi, S. O. (1994). Development of capital market under islamic principles. Managing and Implementing Interest-Free Banking/Islamic Financial System içinde (ss. 1-8). Kuala Lumpur.

Bollerslev, T. (1986). Generalized autoregressive conditional heteroskedasticity. Journal of Econometrics, 31(3), 307-327.

Bousalam, I. ve Hamzaoui, M. (2016). Impact of ethical screening on risk and returns: The case of constructed Moroccan islamic stock indexes. Munich Personal RePEc Archive, (68979), 1-20.

Çelik, İ., Kılıç, M. B. ve Kaya, M. (2017). Farklı dağilim varsayimlari altinda volatilite kaliciliği ve half-life ölçütü bağlaminda geleneksel ve islami endekslerin performansi: Türkiye örneği. 21. Finans Sempozyumu içinde (ss. 275284). Balikesir.

Çevik, E. İ. ve Pekkaya, M. (2007). Spot ve vadeli işlem fiyatlarinin varyanslari arasindaki nedensellik testi. Dokuz Eylïl Üniversitesi İktisadi ve İdari Bilimler Fakilltesi Dergisi, 22(2), 49-66.

Çiçek, M. (2010). Türkiye'de faiz, döviz ve borsa: Fiyat ve oynaklik yayilma etkileri. Ankara Üniversitesi SBF Dergisi, 65(2), 1-28.

Değirmenci, N. ve Abdioğlu, Z. (2017). Finansal piyasalar arasindaki oynaklik yayilimi. Dumlupinar Üniversitesi Sosyal Bilimler Dergisi, (54), 104-125.

Dharani, M. (2012). Behaviour of the shariah compliant shares in India - An Empirical study (Doktora Tezi). Pondicherry University.

El Khamlichi, A., Sannajust, A. ve Sarkar, K. (2014). Islamic equity indices: Insight and comparison with conventional counterparts. Bankers, Markets and Investors, (130), 69-80.

Engle, R. F. (1982). Autoregressive conditional heteroscedasticity with estimates of the variance of United Kingdom Inflation. Econometrica, 50(4), 987-1007.

Fadel, S. M. ve Al-Ajmi, J. (2019). Do trading volume and volatility relationship differs in conventional and islamic stocks evidence from Boursa Kuwait. SSRN Electronic Journal, (December), 1-30. doi:10.2139/ssrn.3331094

Glosten, L. R., Jagannathan, R. ve Runkle, D. E. (1993). On the relation between the expected value and the volatility of the nominal excess return on stocks. The Journal of Finance, 48(5), 1779-1801.

Hammoudeh, S., Mensi, W., Reboredo, J. C. ve Nguyen, D. K. (2014). Dynamic dependence of the global sslamic equity index with global conventional equity market indices and risk factors. Pacific Basin Finance Journal, 30(1), $189-206$.

Hatipoğlu, M. ve Sekmen, T. (2018). Seçilmiş bazı risk faktörlerinin islami borsalar üzerindeki etkileri. MANAS Sosyal Arastirmalar Dergisi, 7(4), 231-240.

Hkiri, B., Hammoudeh, S., Aloui, C. ve Yarovaya, L. (2017). Are islamic indexes a safe haven for investors? An analysis of total, directional and net volatility spillovers between conventional and islamic indexes and importance of crisis periods. Pacific Basin Finance Journal, 43, 124-150. 
Ho, C. S. F., Abd Rahman, N. A., Yusuf, N. H. M. ve Zamzamin, Z. (2014). Performance of global islamic versus conventional share indices: International evidence. Pacific Basin Finance Journal, 28(1), 110-121.

Kayalıdere, K. (2013). Volatilite tahmin modelleri ve performanslarmm ölçümü: Hisse senedi piyasalarnda bir uygulama. Ankara: Gazi Kitabevi.

Korkmaz, T. ve Çevik, E. İ. (2009a). Reel kesim güven endeksi ile İMKB 100 endeksi arasındaki dinamik nedensellik ilişkisi. İstanbul Üniversitesi İsletme Fakültesi Dergisi, 38(1), 24-37.

Korkmaz, T. ve Çevik, E. İ. (2009b). Zımni volatilite endeksinden gelişmekte olan piyasalara yönelik volatilite yayılma etkisi. BDDK Bankacılık ve Finansal Piyasalar Dergisi, 3(2), 87-105.

Lean, H. H. ve Parsva, P. (2012). Performance of 1slamic indices in Malaysia FTSE market: Empirical evidence from CAPM. Journal of Applied Science, 12(12), 1274-1281.

Li, C.-S. (2012). Common persistence in conditional variance: A reconsideration. Economic Modelling, 29(5), 18091819.

Listyaningsih, E. ve Krishnamurti, C. (2016). How is the volatility of jakarta islamic index stocks? Jurnal Bisnis \& Manajemen, 17(2), 109-122.

Nelson, D. B. (1991). Conditional heteroskedasticity in asset returns: A new approach. Econometrica, 59(2), 347-370.

Rana, M. E. ve Akhter, W. (2015). Performance of islamic and conventional stock indices: Empirical evidence from an emerging economy. Financial Innovation, 1(15), 1-17.

Romli, N., Mohamad, A. A. S. ve Yusof, M. F. M. (2012). Volatility analysis of FTSE Bursa Malaysia: Study of the problems of islamic stock market speculation in the period 2007 to 2010. African Journal of Business Management, 6(29), 8490-8495.

Şahin, Ö. (2014). Bist'teki Endekslerin Volatilitelerinin Karşılaştırmah Analizi: Bist Kurumsal Yönetim, Bist 100, Bist 50 ve Bist 30 Endeksleri Üzerinde Bir Uygulama (Doktora Tezi). Düzce Üniversitesi.

Scott, L. O. (1991). Financial market volatility: A survey. IMF Staff Papers, 38(3), 582-625.

Seçme, O., Aksoy, M. ve Uysal, Ö. (2016). Katılım endeksi getiri, performans ve oynaklığının karşılaştırmalı analizi. Mubasebe ve Finansman Dergisi, 72, 107-128.

Shahzad, S. J. H., Ferrer, R., Ballester, L. ve Umar, Z. (2017). Risk transmission between islamic and conventional stock markets: A return and volatility spillover analysis. International Review of Financial Analysis, 52, 9-26.

Sukmana, R. ve Kholid, M. (2012). Impact of global financial crisis on islamic and conventional stocks in emerging market: An application of ARCH and GARCH method. Asian Academy of Management Journal of Accounting \& Finance, 31(2), 357-370.

Yıldız, B. (2016). Oynaklık tahmininde simetrik ve asimetrik GARCH modellerinin kullanılması: Seçilmiş BİST alt sektör endeksleri üzerine bir uygulama. Mubasebe ve Finansman Dergisi, 72, 83-106.

\section{EXTENDED ABSTRACT}

Islamic capital markets can be categorized as stock markets and debt markets in a similar way as conventional capital markets. In Islamic stock markets, Islamic stock indices and Islamic investment funds meet the needs of investors with Islamic sensitivities. The functions and dynamics of Islamic stock markets are no different than its conventional counterparts. When the Islamic stock indices are considered, the stocks included in these indices are selected from among the stocks traded in conventional stock markets within the framework of certain screening criteria. Therefore, an investor who wants to invest in Islamic stock markets will expect a return as a reward for taking risk just like an investor who invests in conventional stock markets. In this context, the fact that people who invest in Islamic stock markets have an idea about the volatility which is a measure of uncertainty will make them expect a more rational return on their investment.

The aim of this study is to forecast the volatility of Islamic and conventional stock indices of Turkey, Malaysia, USA, and UK and to compare the forecasted volatilities. The reasons behind that these countries' stock markets have been examined with Turkey's in this study are as follows; USA: USA has the world's most advanced stock markets in terms of trading volume and market capitalization, the UK: the UK is one of the leading countries in the Islamic finance practices in Europe despite being a non-Muslim country and Malaysia: Malaysia is one of the leading countries in terms of the Islamic finance applications and products. The volatilities were forecasted using GARCH, EGARCH and GJR-GARCH models which are ARCH-types models. The comparison was made according to volatility persistence, half-life volatility, long-term volatility, short-term volatility and the existence of leverage effect.

In this study, following indices represent conventional stock markets for Turkey, USA, the UK and Malaysia respectively; Borsa Istanbul 100 Index (BIST100), the Dow Jones Industrial Average Index (DJIND), the Financial Times Stock Exchange 100 Index (FTSE100), and FTSE Bursa Malaysia KLCI Index (KLCI). Participation 30 Index (KAT30), the Dow Jones Islamic Market US Index (DJISUS), Morgan Stanley Capital International the UK Islamic Index (MSCIUKIS), and FTSE Bursa Malaysia 
Hijrah Shariah Index (HIJRAH) represent Islamic stock markets in the same order of countries. Daily stock returns are used in analysis and computed as the natural logarithmic first difference of daily closing prices. The daily closing price data covers the period of January 6th, 2011 to February 28th, 2018. The reason why the data starts January 6th, 2011 is that the KAT30 was published on this date.

In terms of volatility estimation results, the most appropriate volatility models are GARCH $(1,1)$ for UK Islamic stock market, GJR-GARCH $(1,1)$ for conventional and Islamic stock markets in Malaysia, and EGARCH $(1,1)$ for all other stock markets. The existence of leverage effect is determined for all the markets where EGARCH and GJR-GARCH models are the appropriate estimation models. The existence of leverage effect shows that bad shocks affect the volatility of markets more than good shocks. Countrybased volatility comparison results can be summarized as follows;

The volatility of Turkey Islamic stock market is lower than its conventional counterpart according to four measurements which are volatility persistence, half-life volatility, long-term volatility, short-term volatility. This result is also supported by standard deviation values. The volatility of Islamic stock markets of USA and the UK is higher than the volatility of their conventional counterparts according to the four measurements used. However, it should be noted that the volatility of the UK Islamic stock market is very close to that of the conventional stock index. These results, as well as in the analysis conducted for Turkey, is supported by standard deviation values. According to the volatility estimation results of the Malaysia stock market, volatility persistence and half-life volatility of the Islamic stock market are less than its conventional counterpart. However, the long-term volatility and daily volatility of the Islamic stock market is slightly higher than the conventional market. Nonetheless, the difference is very low.

When the volatilities of Turkey, USA, the UK and Malaysia Islamic stock markets are compared, it is seen that the Turkey Islamic stock market has the lowest volatility persistence and half-life volatility values. Malaysia Islamic stock market has the lowest long-term volatility and daily volatility. While the volatilities of the UK and USA Islamic stock market higher than Malaysian, Turkey Islamic stock market has the highest volatility according to long-term and daily volatility results. These results are almost identical with the standard deviation values of the time series. When standard deviation is taken as a measure of risk, Malaysia Islamic stock market still has the lowest risk, Turkey has the highest one. 